\title{
Articles
}

\section{Typing Wilde: Construing the "Desire to Appear to Be a Person Inclined to the Commission of the Gravest of All Offenses"*}

\section{Ed Cohen}

That was the consequence of their being too bad to be talked about, and was the accompaniment, by the same token, of a deep conception of their badness.

Henry James, The Ambassadors

On 28 February 1895 Oscar Wilde arrived at his club, the Albemarle, after an absence of several weeks and was presented with an envelope containing the Marquis of Queensberry's calling card. On the back of the card were scrawled the words: "For Oscar Wilde Posing as a Somdomite [sic]."1 As the culmination of months of harassment by the

* Copyright (c) 1993 by Routledge, Chapman and Hall, Inc. The Yale Journal of Law \& the Humanities would like to thank Ed Cohen and Routledge for permission to reprint this article, with slight modifications, from Ed Cohen's Talk on the Wilde Side: Toward a Genealogy of a Discourse on Male Sexualities (1993).

1. Actually the handwriting on the card is so bad that it is difficult to make out exactly what the text says. Indeed, at the committal hearing the court was forced to ask the Marquis of Queensberry 
Scottish aristocrat-who objected to Wilde's intimacy with his youngest son, Lord Alfred Douglas-the short text so incensed Wilde that it incited him to instigate legal action against its author. Filing charges under the 1843 Criminal Libel Act (6 and 7 Vict. I, c. 96), Wilde's legal representatives asked the court to interpret the marquis's text as a verbal attack upon his person and to hold its author criminally responsible for the consequences of his writing. Unfortunately for Wilde, the statute invoked on his behalf allowed the accused party a unique form of rejoinder: the defendant could assert his innocence by placing a competing interpretation of the alleged libel before the court-in what was termed a "plea of justification"-which sought to prove that the offending statement was both "true" and "published for the public benefit." If the court verified that both these conditions obtained, then the defendant would be deemed innocent of the charge and the libel found to be legally substantiated. Needless to say, the Marquis of Queensberry's lawyers quickly countercharged that such was the case. This defense tactic effectively transformed the legal proceeding in Wilde v. Queensberry into an interpretive contest both for determining the text's "true" meaning and for assessing its social significance. Hence, what was at stake in the proceedings of Wilde v. Queensberry was not simply whether or not the writing on the Marquis of Queensberry's card constituted a libel against Wilde, but also what it meant "to pose as a sodomite," whether Wilde had done so, and if publishing the knowledge of such a "pose" was in the public interest.

Framed by the tenor of these questions, the trial necessarily foregrounded the specificity of the phrase "posing as a sodomite." Since the contested statement did not actually accuse Wilde of "sodomy"of being a sodomite - for which a strict standard of legal proof (i.e., proof of penetration) would have been required, the defense sought instead to show that Wilde was the kind of person-or at least that he had (re)presented himself as the kind of person-who would be inclined to commit sodomy. In support of this personification, the plea of justification tried to shift the legal focus on sodomy away from its traditional status as a criminally punishable sexual act so that it became in the defense's construction a defining characteristic of a type of sexual actor (the "sodomite"). In order to provide a credible standard of proof for this characterological claim, the defense's plea of justification listed thirteen allegations that "Oscar Fingal O'Flahertie Wills Wilde ... did solicit and incite ... [another male person] to commit sodomy and other

to read it aloud in order to verify the alleged libel. There is some speculation that the words may actually have read "For Oscar Wilde-Ponce and Somdomite" and that the marquis was encouraged by his legal representatives to interpret them as "posing as" in order to strengthen his case. Given the marquis's general infelicity with words and the incredible importance that the phrase "posing as" had for the defense case, it seems not implausible that this rendering of the libel's text was shaped by legal counsel. 
acts of gross indecency." Here, playing upon the indeterminacy introduced by the word "posing," the defense interpretation subsumed the specific cultural and legal history evoked by the word "sodomy" with the newer, relatively unknown category, "acts of gross indecency," metonymically subsuming the former within the behavioral penumbra of the latter. Thus, even as the defense plea displaces "sodomy's" historical privilege as the sole basis for criminalizing sexual acts between men and constitutes it as one of a number of "other acts of gross indecency," the earlier concept is simultaneously recouped by the defense plea as the legitimating criterion through which a much wider variety of "indecent" relationships between men can be brought within the legal purview.

Yet even if the court was inclined to agree that by incorporating the residual meanings ascribed to the older sexual offense within their indefinite use of an emergent legal category the defense had legitimated the "truth" of the statement that Wilde had "pos[ed] as a sodomite," the Marquis of Queensberry was still required to demonstrate that the publication of the statement was for "the public benefit." In order to satisfy this condition, Queensberry's plea of justification shifted its concern from Wilde's sexual to his literary practice. Claiming that "Oscar Fingal O'Flahertie Wills Wilde was a man of letters and a dramatist of prominence and notoriety and a person who exercised considerable influence over young men," the plea charged

that the said Oscar ... Wilde in the month of July in the year of Our Lord One thousand eight hundred and ninety did write and publish and cause and procure to be printed with his name upon the title page thereof a certain immoral and obscene work in the form of a narrative entitled "The Picture of Dorian Gray" which said work was designed and intended by said Oscar ... Wilde and was understood by the readers thereof to describe the relations, intimacies, and passions of certain persons of sodomitical and unnatural habits, tastes, and practices. ${ }^{2}$

Here, Wilde's text becomes the pretext for the assertion that his sexual practices were relevant public knowledge. Interpreting the interactions between the male characters in The Picture of Dorian Gray as a reflection of the "sodomitical and unnatural" relations that Wilde was supposed to have engaged in his life-a far from self-evident interpretation, as the subsequent critical commentary on the novel makes clear ${ }^{3}$ - the defense

2. Similarly, the plea also charged that Wilde's "Phrases and Philosophies for the Use of the Young" was a corrupting influence against which the public should be forewarned, in this case not because the work itself depicted "the practices and passions of persons of sodomitical and unnatural habits and tastes," but because it appeared in a magazine, The Chameleon, containing another work, "The Priest and the Acolyte" (not written by Wilde), that did.

3. While The Picture of Dorian Gray has provoked allusions to its "immorality" ever since it was first published, few critics have bothered to consider how a text that (re)presents no sexualized relations between men has been so consistently (if not universally) understood to depict erotic 
plea introduces a theory of representation that defines Wilde's text as a vehicle "calculated to subvert morality and to encourage unnatural vice." By proposing a hermeneutic that fixes the literary work as a form of (in this case, counterhegemonic) sexual didacticism, Queensberry's defense sought to hold the author morally and legally responsible for the implications of his writing. However, by linking the claim that Wilde was a particular type of sexual "character" (and not that he had committed certain sexual acts) to a suggestion that this characterization had larger social implications because he was a writer, the plea introduces the possibility of reading Wilde's sexual proclivities into his writing in order to confirm him as a "certain person of sodomitical and unnatural habits, tastes, and practices." In other words, by foregrounding the literary text as an indication of its author's (and perhaps also its readers') sexual characteristics, the plea attempts to construct a way of discerning and subsequently signifying sexual "tendencies" without reference to sexual acts.

Throughout the two and a half days of the trial, then, the Marquis of Queensberry's barrister, Edward Carson, undertook to impress upon the court not that Wilde had engaged in any specific sexual acts with any of the men listed in the plea, but rather that Wilde-in both his life and in his writings-had demonstrated a "tendency" toward "indecent" (i.e., nonnormative) relationships with other men. Hence, when Wilde's barrister, Sir Edward Clarke, rose in the midst of the opening speech for the defense to ask the court's permission to withdraw the prosecution against Queensberry, he did so by referring only to the imputations made against Wilde's writing-albeit in order to circumvent the defense's introduction of evidence about his client's sexual practices. Unfortunately, by interrupting their prosecution to protect Wilde from the incriminating testimony that the defense appeared to have gathered against him, Wilde and his legal representatives effectively forced the court to find in the Marquis of Queensberry's favor. The short text scrawled on the back of the marquis's calling card, therefore, precipitated a legal contest that ended not only by affirming that Queensberry's words, "For Oscar Wilde Posing as a Somdomite," were "true" and "for the public benefit," but also by culling enough evidence to indict and ultimately to convict Wilde for committing acts of gross indecency. ${ }^{4}$

intimacies between its male characters. For an analysis that attempts-without resorting to crude biographical reductionism-to specify how the text signifies its counterhegemonic sexual meanings, see my "Writing Gone Wilde: Homoerotic Desire in the Closet of Representation," PMLA 102.5 (October 1987): 801-13.

4. Oscar Wilde's unsuccessful prosecution of Queensberry for libel was the first of three trials involving Wilde. In its criminal prosecution of Wilde-the second and third of the three trials-the Crown largely based its case on the evidence gathered by Queensberry for his defense in the libel trial. This article focuses on the libel trial, Wilde v. Queensberry. For an analysis of the Crown's prosecution, conviction, and sentencing of Wilde for committing "acts of gross indecency with another male person," see my Talk on the Wilde Side: Toward a Genealogy of a Discourse on Male Sexualities (New York: Routledge, 1993), 173-209. 
As this scenario suggests, the proceedings in Wilde v. Queensberry were framed by the transformations in legal discourse from "sodomy" to "gross indecency." However, since in this case the question before the court concerned only Queensberry's legal culpability for his accusation that Wilde had "posed as a sodomite" and not Wilde's legal culpability for the sexual act per se, the finding in the case was not a critical moment in crystallizing the shifting legal relationship between these categories. Yet beyond a small circle who were intimates of the prosecutor and the defendant themselves (and subsequently for legal historians), these specifically juridical issues were greatly overshadowed by the interpretive effects (re)produced in the journalistic accounts of the trial. For, when it was splashed across the pages of almost every London newspaper and in fact across the front pages of most newspapers throughout Europe and North America, the "story" of "OSCAR \& MARQUIS" (as the banner of the Evening News declared it) transformed the courtroom's narrower questions of legal culpability into larger ones concerning social/sexual meanings. If, as literary critic Mikhail Bakhtin has suggested, trials have historically proved a critical element for narrative development by linking the knowledge effects of juridical authority to more diffuse cultural practices, then the narratives of Wilde's legal proceeding can be situated within a historical pattern of interpretation that privileged the trial as a site for the production of meaning. ${ }^{6}$ Hence, unlike the courtroom proceedings themselves, whose "interpretations" were delimited by the (nonnarrative) logic of the legal contest, the journalistic representations of the trials produced narratives from which a range of social significance could be read off. As the impetus for such trial narratives, the libel's text therefore became a pretext for producing a series of second order (con)texts that not only communicated the "events" of the legal proceedings from the relative obscurity of a Central Criminal Court chamber to the ubiquity of a national reading audience, but also rendered these proceedings as meaningful social practices. Indeed, by constituting their representations as "newsworthy," the news-

5. For a fuller discussion of these transformations, see my Talk on the Wilde Side, 103-25.

6. M. M. Bakhtin, The Dialogic Imagination, trans. Caryl Emerson and Michael Holquist (Austin, Tex.: University of Texas Press, 1981), 388-94. In his discussion of "the trial" as a "fundamental organizing idea in the novel" (388), Bakhtin is referring primarily to the word "trial" as a "test" or "challenge" that recoups the narrative structure of Christian hagiography or chivalric romance for modern genres. Yet Bakhtin's analysis also applies to the case of courtroom trials inasmuch as his usage derives the trial's narrative specificity from its "testing [the hero's] discourse" (388)-a definition that succinctly encapsulates the discursive function of the juridical trial. In Wilde's case, Bakhtin would seem to underscore the cultural intertext that made the trial's narratives accessible, if not marketable, when he writes that

the testing of a strong personality who opposes himself on one ground or another, to the community, who seeks to attain complete self-sufficiency and a proud isolation, or who aspires to the role of a chosen leader; the testing of the moral reformer or amoralist, the trial of the Nietzschean man or the emancipated woman and so forth-these are all very widespread organizing ideas in the European novel of the nineteenth and early twentieth century (389-90). 
paper reports defined the trials as exemplary and thereby rearticulated the courtroom contest between the two interpreters of Queensberry's text as a struggle between moral, legal, sexual, political, and aesthetic ideologies.

Given the highly emotional resonance of the criminal charge and countercharge, it is hardly surprising that the form that this journalistic rearticulation took was often "dramatic"-or indeed, "melodramatic."7 While the particular styles of (re)presentation varied greatly from paper to paper, ranging from the staid, microscopic, monologic prose of the Times to the bold, sensational, illustrated pages of the Morning Leader, these texts were almost universally constituted and sold as dramatic narratives. To some extent, this choice of narrative mode derived from the excitement of the courtroom itself, where Wilde's polished testimony under direct examination and his highly ironic and often devastatingly funny replies to the defense cross-examination enveloped the proceedings in the "drama" of his own self-(re)presentation. For example, the heated dialogue between Wilde and his cross-examiner, Edward Carson, so captured the public imagination that it became a set piece in all subsequent depictions of the case. Yet beyond the formidable influence of Wilde's person(a), the formal organization of the public knowledge about the trial was also constrained by the cultural nexus that constituted "the news."

At a functional level, news can be described as a mode of information that is sold as a commodity on a regular (daily/weekly) basis. As such, it is structured by two fundamental demands: currency and marketability. During the last third of the nineteenth century, the emerging British mass-market newspaper industry addressed these demands by introducing both new technologies (i.e., by developing new high-speed means for information gathering, printing, and distribution) and new discursive strategies (i.e., by adapting the narrative modes developed in earlier forms of popular literature to the representation of "current events"). After the 1880s, when the rising capital expenses of newspaper production necessitated the development of increasingly popular styles of journalistic reporting, the emergence of a distinctly different kind of journalism-which Matthew Arnold named "the new journalism"-

7. Peter Brooks, The Melodramatic Imagination (New Haven: Yale University Press, 1976), argues that as a "system of meaning" melodrama provided the nineteenth century with a "fiction[al] system for making sense of experience" that "has the distinct value of being about recognition and clarification, about how to be clear about what the stakes are and what the representative signs mean, and how to face them." If, as I suggest in Talk on the Wilde Side, 119-25, sexual scandals constitute a liminal moment in cultural history during which normative values and practices are contested, then the melodramatic mode would seem to provide a highly effective means for resolving such cultural indeterminacy into clearly defined alternatives and for organizing the production of meaning around them. For a parallel consideration of melodrama apropos of the famous $W$. $T$. Stead scandal, "The Maiden Tribute of Modern Babylon," see Judith Walkowitz, City of Dreadful Delights (Chicago: University of Chicago Press, 1992). 
foregrounded the significance of "telling a story" in order to increase newspaper circulations. As epitomized by William Stead's editorship of the Pall Mall Gazette, the new styles sought to establish an emotional relationship to the audience by drawing upon personalized narration, vivid language, evocative detail, and, most important of all, sensational subjects. While not all newspapers took up the extreme versions of these strategies found in the pages of the Pall Mall Gazette or the popular Sunday papers, to some extent journalistic practice was itself transformed by the narrative expectations they engendered.

In their attempts to popularize the journalistic text and thereby cultivate large and diverse readerships, the new journalism's strategies can be seen to have foregrounded the narrativity of its "stories." Embedded in newspaper (con)texts, the "facts" were necessarily mediated by the apparatus of representation so that their "truth" was intimately connected to their "significance" and their marketability. By focusing on the analysis of the press's representations of Wilde v. Queensberry, therefore, I hope to explore both how particular alternatives for male sexual behavior were defined in Britain at the end of the nineteenth century and how meanings were popularly attributed to them. More specifically, by analyzing the ways in which the journalistic accounts portrayed Wilde's "character" and situated this character within the narrative of a libel proceeding that ultimately found the Marquis of Queensberry justified in stating that Wilde "posed as a sodomite," I hope to examine the process whereby a cultural concept signifying a particular type of male individual who had a "tendency" toward committing sexual acts with other men was constructed. For, in the course of representing the libel proceedings in Wilde v. Queensberry, the newspapers effectively (re)produced the possibility for designating Wilde as a kind of sexual actor without explicitly referring to the specificity of his sexual acts, and thereby crystallized a new constellation of sexual meanings predicated upon "personality" and not practices. ${ }^{8}$

8. In the following pages, I draw on the reports of Wilde v. Queensberry found in eighteen London newspapers: twelve dailies and six Sunday papers. Since the daily papers provided day by day accounts of the proceedings that took place from Wednesday 3 April through Friday morning 5 April 1895, followed by the reports of Wilde's arrest on Friday afternoon and subsequent indictment on Saturday 6 April, their narratives differ significantly from those in the Sunday papers appearing on April 7 (Reynolds's, The People, News of the World, Weekly Dispatch, Lloyd's Weekly Newspaper, Illustrated Police Gazette). For, in the latter-whose circulations eclipsed those of the dailies by hundreds of thousands-the "story's" denouement (i.e., Wilde's arrest on charges of committing "acts of gross indecency") could always already be read back into its beginning. In addition, the dailies themselves can be divided into morning (Times, Morning Leader, Morning, Daily Telegraph) and evening papers (Evening Standard, Star, Echo, Evening News, Pall Mall Gazette, Westminster Gazette, St. James Gazette, Globe), with the latter often providing less-complete accounts of the day's proceeding than the former in part due to earlier deadlines. This pattern is especially pronounced on Friday 5 April, when the events changed radically from morning to evening.

More significantly for my purposes, the newspaper accounts can be roughly divided into three distinct groups according to narrative mode. One group signaled by their manifestly unanalyzed "transcription" of opening speeches, examination, and cross-examination, by their lack of narrative 


\title{
IN ChaRACTER
}

The headlines that appeared after the first day of testimony in Wilde $v$. Queensberry (see figures 1-4) announced the spectacular nature of the events that were unfolding inside the chambers at the Old Bailey. Like the playbills of a West End theater or the chapter summaries of a sensation novel, the banners that heralded the news reports of the trial on the evening of 3 April and the morning of 4 April 1895 sought to arouseand then capitalize upon-the expectations of the prospective audience. With Wilde and the Marquis of Queensberry vying for top billing among

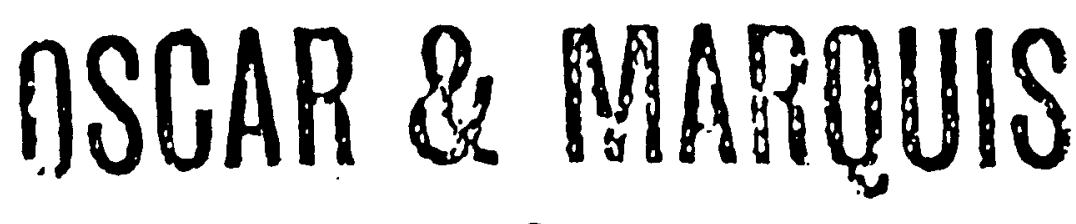

\section{The Strange Libel Case Opened.} SGENE IN COURT.

\section{A Remarkable Letter to Lord Alfred Douglas}

Figure 1. The Evening News, 3 April 1895.

\begin{abstract}
interruptions, and by their almost fetishistic attention to detail that they provided "verbatim" accounts of what had transpired in the courtroom (Evening Standard, Echo, Daily Telegraph). A second group, while also purporting to provide complete accounts of the proceedings, had a much more highly dramatized and intrusive narrative voice which both set the scene-graphically and interpretively - and foregrounded the significance of particular elements in the case with welldeveloped editorial asides and commentary, interpretive subheadings, and illustrations (Evening News, Star, Morning Leader, and all the Sunday papers). The third group, while not professing to provide detailed accounts, instead offered digests of the proceedings either with (Pall Mall Gazette, Westminster Gazette) or without (Times) editorial commentary. In all three cases, however, it is important to remember that the texts are always pastiches, comprised of direct and indirect quotation, paraphrase, description, commentary, and, quite crucially, omission, in varying proportions.
\end{abstract}




\section{OSCAR WILDE}

\section{DEFENDS HIMSELF AT THE OLD BAILEY.}

\section{CHARGES BROUGHT AGAINST HIM BY LORD QUEENSBERRY.}

\section{The Asthote Gives Characteristically Crnical Evidence, Replote with Polnted Epigram and Startlink Paradox, and Explains His View on Morality in Arl.}

Figure 2. The Star, 3 April 1895.

a remarkable cast of characters (including several legal luminaries and a potential parade of young working-class men), and with much of the dialogue provided by one of the West End's most popular playwrights himself, the drama promised to be highly entertaining.

To belabor the theatrical metaphor a bit, like the borders of the proscenium these headlines quite literally "frame" Wilde: i.e, they use his name to mark the text out both spatially and interpretively, defining the epistemological stage upon which the action unfolds. Designed to attract the eye's attention from a page of otherwise minute print, the words "OSCAR WILDE" in enlarged typeface, often in a different font, not only denote the text's point of origin, both typographically and narratively, but also provide an organizing principle for the "copy" that follows. Since, as this journalistic jargon suggests, the newspaper texts largely reiterate their headline in various forms, returning again and again to the signifiers emblazoned there, they continually reconstitute and reinscribe the signs that designate their origin. Thus, the words "Oscar Wilde" appearing in bold-faced, large print at the top of a page of 


\section{OSCAR IN THE BOX. THR MARQUESS IN THL DOCK.} MOST SERIUUS OHARGES FOKMULATED AGAINST MR. WILDE. OBCAR ANSWENG THIK BT AN ADSOLUTE DENILL-HE TURNB RXTEMPORANICUS FPIORAN8, LND EXCEANGES VIEW'B OF METAPnY8ICS, ETUICs AND ART WITH MR. OLRBON, Q.C., IVHO OPPOSES THE PIAY OF ORCARIBA WITH DIRECT SUGGTRTIONS OF IMMORALITY.

Figure 3. The Morning Leader, 4 April 1895.

newsprint "frame" Wilde not only in the sense of putting a frame around "his story" (textually) or marking it out from a background (spatially), but also in the colloquial sense that they "frame" him for a crime. For, although Wilde is nominally and legally the prosecutor in the case, the headlines make it clear that he is the one who is in the public spotlight. To take the Morning Leader (figure 3) as a paradigmatic instance, the paper made "OSCAR IN THE BOX" the origin-if not the meaningof the story, turning Wilde into the subject of both legal and journalistic examination and therefore mitigating the case's legal and historical context. In the Star's version (figure 2), "OSCAR WILDE • Defends Himself at the Old Bailey - Charges Brought Against Him by Lord Queensberry," the Tory paper actually inverts the legal position of the two litigants, literally depicting Wilde as the accused and Queensberry as the accuser. By connecting the newspaper text to a larger cultural context in which "Oscar" or "Oscar Wilde" (re)produced certain aesthetic/ sexual meanings and by simultaneously focusing the ensuing narrative on Wilde himself, these headlines structure their signifying processes around 


\title{
OSCAR WILDE LIBEL CASE.
}

\author{
TRIAL $\Lambda T$ THE OI.D BAILEY. \\ LORD QUEENSBERRY IN THE DOCK. \\ I'LFA OF: JUSTIFICATION.
}

Figure 4. The Pall Mall Gazette, 3 April 1895.

the construction of a "character" whose idiosyncrasies will come to define a "type" of individual.

To some extent this characterological orientation reflects the fact that the extensive press coverage given to this particular litigation undoubtedly derived-at least initially-from Wilde's public status as a popular playwright and as a (self-marketed) cultural icon. Indeed, at the time of the trial, Wilde was unquestionably at the height of his commercial and literary success: two of his comedies, An Ideal Husband and The Importance of Being Earnest, were simultaneously playing to the delight of West End audiences and his earlier dramatic works, $A$ Woman of No Importance (1893) and Lady Windermere's Fan (1892) had garnered him much critical acclaim and financial remuneration in the preceding two years. In addition, the scandal that Wilde's novel The Picture of Dorian Gray caused on its initial appearance in Lippincott's Monthly Magazine (when the newsagent W. H. Smith refused to sell the issue) and then again a year later when it appeared in an expanded bound edition, contributed to his reputation both as a litterateur and as a provocateur. ${ }^{9}$

Yet even more than his status as a successful contemporary author, it was Wilde's self-produced image as a unique (if not outré) cultural figure that catalyzed the public interest in the trial. From the moment he left Oxford (in 1879) and went down to London, where due to his father's death and the ensuing familial insolvency he was forced for the first time to earn his income, Wilde had self-consciously marketed himself as a liminal figure within British society. His highly publicized tour of America in 1881 as the front man for Richard D'Oyly Carte's U.S. production of Gilbert and Sullivan's Patience not only established him as an iconic embodiment of the "aesthetic" type that the operetta parodied, but also demonstrated his ability to sell his association with this stylistic critique

9. Stuart Mason (Christopher Millard), Oscar Wilde: Art and Morality (1907; rpt. New York: Haskell House Publishers, 1971) provides a selection of the critical reviews that appeared in the press after Dorian Gray's publication. See especially Wilde's exchange with the reviewer from the Scotts Observer. 
of bourgeois respectability-and especially male respectability-as a cultural commodity in its own right. ${ }^{10}$ In her book, Idylls of the Marketplace: Oscar Wilde and the Victorian Public, Regenia Gagnier forcefully argues that Wilde's self-positioning as a "dandy" represented a highly developed criticism of middle-class ideologies and particularly those for male gender identity. She counterposes the figure of "the dandy" to that of "the gentleman," and his prototype "the public school boy," in order to illustrate that Wilde's personal aesthetic constituted an embodied challenge to the social and cultural-if not the economic-hegemony of the Victorian bourgeoisie. ${ }^{11}$

Given this counterhegemonic positioning, it is hardly surprising that during the 1880s Wilde's sartorial and aesthetic statements became the object of much disapprobation and satire. He was often caricatured in contemporary journals as a languorous, long-haired lover of sunflowers or as an "utterly" aestheticized utterer of epigrams, so that the representation of his large, lounging frame became an iconic disparagement of what was deemed to be male "effeminacy." It is important to note here that the "effeminacy" popularly attributed to the "aesthetic" or "decadent" movement had not yet produced an immediate corollary association with sexual relations between men. In fact, as the representation of Bunthorne in Patience illustrates, this effeminacy was often seen to align the "aesthetic" male with the domestic realm of the female, making him a more sought after object of female desire, if only because of a perceived commonalty of interests. ${ }^{12}$ The supplementing of "aesthetic" effeminacy with connotations of male sexual desire for other men is, I would argue, one of the consequences of the newspaper representations of the Wilde

10. A show at the Metropolitan Museum of Art entitled "In Pursuit of Beauty: Americans and the Aesthetic Movement" displayed several trade cards and advertisements that played upon this very association to market their products. For example, the advertisement for Garland Stoves portrays a young woman (whose head is haloed by Wilde's floral familiar, a giant sunflower) aesthetically arranged in a well-appointed interior complete with lily. The caption to the picture draws all these references together precisely by invoking Wilde's name: "Aesthetic stoves are all the style / Some very tame, some very 'Wilde,' / GARLANDS are always the best / Far excelling all the rest." I thank Peter Gibian for bringing these cards to my attention.

11. Regenia Gagnier, Idylls of the Marketplace: Oscar Wilde and the Victorian Public (Stanford: Stanford University Press, 1986), 51-99. Ellen Moers's classic work The Dandy: Brummell to Beerbohm (New York: Viking, 1960), 294-308, also situates Wilde's "aestheticism" in relation to the ideological constructions of "the gentleman," but her approach is primarily anecdotal.

12. One might speculate that this parodic association of the "aesthetic" male with the "effeminacy" of the "female" domestic realm was predicated upon the anxiety generated in middleclass men by the Victorian ideology of "separate spheres." Since bourgeois men were supposed to be absent from the home during the day while engaged in their "productive" endeavors, they necessarily had little in common with their wives whose world was meant to be focused almost exclusively on this "private" arena. The figure of a male who took an interest in the aesthetic of the domestic, then, necessarily threatened the precarious balance of such polar relationships and as a consequence was impugned as "unmanly"-i.e., "effeminate"-in order to recode this threat while maintaining the prevailing ideology of gender separation. The contradiction inhering in the image of the "aesthete" as both "ladykiller" and "effeminate" would thus reproduce the strategic transformation of a (real?) fear into its (ideological?) antithesis and illustrate the means by which a dominant ideology recoups such interruptions within its structures of difference. 
trials. Hence, instead of marginalizing Wilde by depriving him of the legitimacy accorded to middle-class male "authority," these characterizations of Wilde as "aesthetic" or "effeminate" ironically served to publicize his style even more widely-as Ellen Moers writes, "in the fin de siecle, caricature, however insulting, was counted good publicity"13 - and were thus instrumental in producing "Oscar" as one of the best-known "personalities" of the late-Victorian period.

By playing upon these indexical connotations of Wilde's commoditized self-image, the newspaper headlines testify that the semiotic shift from proper name to cultural category is predicated on the unarticulated nexus of difference (or "ideology") that overdetermines "Oscar" as a meaningful signifier. The Evening News's banner "OSCAR \& MARQUIS" (figure 1) provides an explicit example of the strategy whereby the overly and overtly familiar "Oscar" is opposed to and conjoined with the aristocratic tag "Marquis" to denote not only the two sides of a "strange libel case" or two distinct class positions but, as the ensuing text will reveal, two poles of male behavior. Referring to Wilde paradigmatically as "The Aesthete," the Star (figure 2) prefaces its coverage by suggesting that Wilde embodied a cultural category for which definite "characteristics" can be isolated. Since the specifics of this characterological typology situate Wilde in a duplicitous relation to languagemarked by "cynical evidence," "painted epigram," and "startling paradox"-the headline positions the reader to confirm (or possibly to negate) this interpretation in the following representations of his testimony and thereby engages the reader in the (re)production of this category. Similarly, the Morning Leader's subhead (figure 3) transforms Wilde's name into a noun phrase, "The Play of Oscarism," denoting a certain "characteristic" relation to language that it then juxtaposes to "The Direct Suggestions of Immorality" articulated by Queensberry's barrister. This opposition serves to reinforce the implication that Wilde's linguistic "indirection" hides the actual "immorality" that Edward Carson's "direct" speech reveals and thus it organizes the text around articulating the relation between the "unrepresented" and the "unrepresentable": i.e., between language and sexual relations between men.

By foregrounding the role that language plays in the representation of Wilde's (sexual) experience-both by Wilde himself and subsequently by the press-the newspapers call attention to the explicitly interpretive, or even "fictional," quality of their accounts and thereby underscore the narratives' production of meanings. Indeed, this productive process is implicitly evoked by several of the opening paragraphs which, in their devotion to describing the crowded courtroom "scene" on the morning

13. Moers, Dandy, 296. 
of 3 April, interpellate readers as an active "audience" whose attendance is deemed semantically critical to the story.

The Importance of Being Early was never better illustrated than at the Old Bailey this morning when long before 10 o'clock every seat where a pressman could sit had a couple of competitors for it. . . (Evening News)

Not for years has the Central Criminal Court at the Old Bailey been so densely crowded as it was this morning. People begged, bullied, and bribed for admission. ... (Star)

Quite an hour before the day's business opened at the Old Bailey this morning people were using every effort to gain admission to the old court. (Echo)

Never, perhaps in the history of the old court has there been such organized demand for admission on the part of persons of apparent position; never, perhaps, have so many prominent persons been disappointed to find their prominence would not serve to gain them entrance to a criminal court. (Morning Leader)

Almost as if evoking an oversold opening night on which avid theatergoers "beg, bully, and bribe for admission" to the latest Wilde production-and in the Morning Leader's version, on which even "prominent persons" are turned away-these passages underscore the "drama" of the case while simultaneously transforming the image of the packed chambers into a metaphor for the uniqueness, the "newsworthiness," the overwhelming significance of the events. This is not just any court proceeding, the papers seem to suggest, it is a proceeding about which important people very much want to know. The tiny, crammed courtroom, thus, comes to signify not just those men who managed to squeeze into a particularly small and highly charged geopolitical space-and they were exclusively men in the restricted chambers of the Old Bailey, as the Morning notes-but also metonymically becomes the textual mark of a larger (reading) audience who can only "know" through the press. By infusing the metaphor of the courtroom as theatrical extravaganza with the textual markings of epistemological desire, the newspapers structure their texts as "spectacular," (re)producing what Roland Barthes called "myth": they imbue their first-order representations of the "facts" and "events" (denotation) with a second order of significance that naturalizes the social (con)texts within which these meanings emerge (connotation). ${ }^{14}$ Yet as Barthes would later comment, the supposed "first order" is itself ideologically constructed such that "denotation is not the first meaning, but pretends to be so; under this illusion it is ultimately no

14. Roland Barthes, Mythologies, trans. Annette Lavers (New York: Hill and Wang, 1972), 10959. 
more only than the last of the connotations."15 Thus, the dynamic interplay between these levels of meaning in the newspaper accounts serves to legitimate both the facticity of "the events" and the authority of their narrative interpretations.

In the ensuing descriptions of the litigants, the juxtaposition of Wilde to the Marquis of Queensberry as two distinct-if not antithetical-icons of masculinity inscribes this mythic economy at and as the inception of the newspaper narratives. For, as each of the men comes not only to represent "himself" but also to signify a particular male "type" (e.g., the profligate and somewhat degenerate aristocrat $v$. the effusive and somewhat effeminate dandy), the story of their legal conflict also becomes the symbolic renegotiation of the categories of difference that motivate these typologies. The Morning Leader provides the most florid version of this pattern:

Bound to recur and startle the world, whether it be with sunflowers or sonnets, plush or paradox, whether in the domain of art or in society, Oscar Wilde is again what he has before made himself, the talk of every tongue and the cynosure of fame or notoriety or ridicule-he does not pretend to care which, not being an ordinary person. John Sholto Douglas, Marquis of Queensberry, has also been, on another plane, a public person seen in many kaleidoscopic lights, and when these two meet at such issues as are involved in the WildeQueensberry case, opened yesterday at the Old Bailey, the intensity of public interest is phenomenal. (4 April)

Accompanied by line drawings of the two men, a slightly smiling, affable profile of the Marquis of Queensberry and an enlarged grotesque of Wilde's head, replete with ponderous lips, monstrous nose, and bloated cheeks (see figures 5 and 6), this paragraph underscores the "extraordinary" character of both the legal contest and the legal contestants. Here Wilde is identified with the effects of his "persona," associated with "sunflowers or sonnets," "plush or paradox," details that evoke both the extravagance and decadence of his dandiacal self-production ("[being] again what he has made himself before"). Moreover, in conjunction with the grotesqueness of the accompanying drawing, they body forth the physical degeneration that such nonnormative, non-"manly" practices portend. The Marquis, on the other hand, while also described as a "public person," is not similarly associated with the details of his personal history (which included a much-publicized disruption of Tennyson's Promise of the May, a bitter divorce followed by public cohabitations with his mistresses, and a series of vituperative attacks on both the queen and the prime minister, Lord Roseberry, for proffering

15. Roland Barthes, $S / Z$, trans. Richard Miller (New York: Hill and Wang, 1974), 9. 
his son a peerage); ${ }^{16}$ instead Queensberry is portrayed both verbally and graphically as incarnating "neutral" masculinity.

The Evening News in its juxtaposition of the two men makes the implications of these two visions of maleness even more explicit:

Lord Queensberry, who disdained a seat, stood in front of the dock with his arms folded, occasionally changing his attitude to make note of something that occurred to him. While Wilde was in the box the peer looked implacably across the court to where the poet, with his hyacinthine locks and air of easy abandon, almost lolled in the witness box. (3 April)

Queensberry, the erect, stalwart, "peer" "who disdained a seat," here personifies the attitude of masculinity rampant: arms crossed, unbreachable, an image befitting his own heraldic crest, a virtual icon of outraged masculinity. The narrative voice identifies with Queensberry's positioning and reports, as if through the marquis's "implacable" gaze, the contrasting portrait of "the poet": soft, floral, unrestrained, Wilde seems to recline in the witness box: i.e., he disdains the importance of his surroundings and appears without respect for the laws of realm or man (see figure 7). The images of the two men provide a studied contrast, almost as if they represented the "do" and "don't" panels in a Victorian etiquette book. ${ }^{17}$ This tableau, in turn, became a set piece in the descriptions of the trials so that, for example, when the Star reported the opening of the second day of the trial, it reiterated these postures exactly:

[T] he noble defendant, clad in a dark blue overcoat with a velvet collar, in place of the rusty black garment of yesterday was admitted to the dock and sat there quietly until Mr. Justice Collins arrived when he resumed his old pose with arms folded on the dock front.

Punctually at half past ten, Oscar was recalled to the witness box. Bland and attentive, his hands limply crossed and drooping or clasped around his brown suede gloves, he awaited the resumption of Mr. Carson's cross-examination. (4 April)

Here the contrasting descriptions of the litigants' body postures evince both a detailed presentation of the courtroom "scene" and a qualitative statement about the "characters." The gestural significance attributed to Queensberry's "arms folded" is defined over and against Wilde's "hands limply crossed," so that the latter can be read as a negation of the male propriety that impels the former. By stylizing the opposition between "Oscar" and "the noble defendant," the newspapers map the underlying determinations of difference that generate such normative assessments of

16. For Queensberry's biography, see Brian Roberts, The Mad Bad Line (London: Hamish Hamilton, 1981).

17. For an analysis of the cultural constructions of Victorian "etiquette," see Michael Curtin, Propriety and Position: A Study in European Manners (New York: Garland Publishing, 1987). 


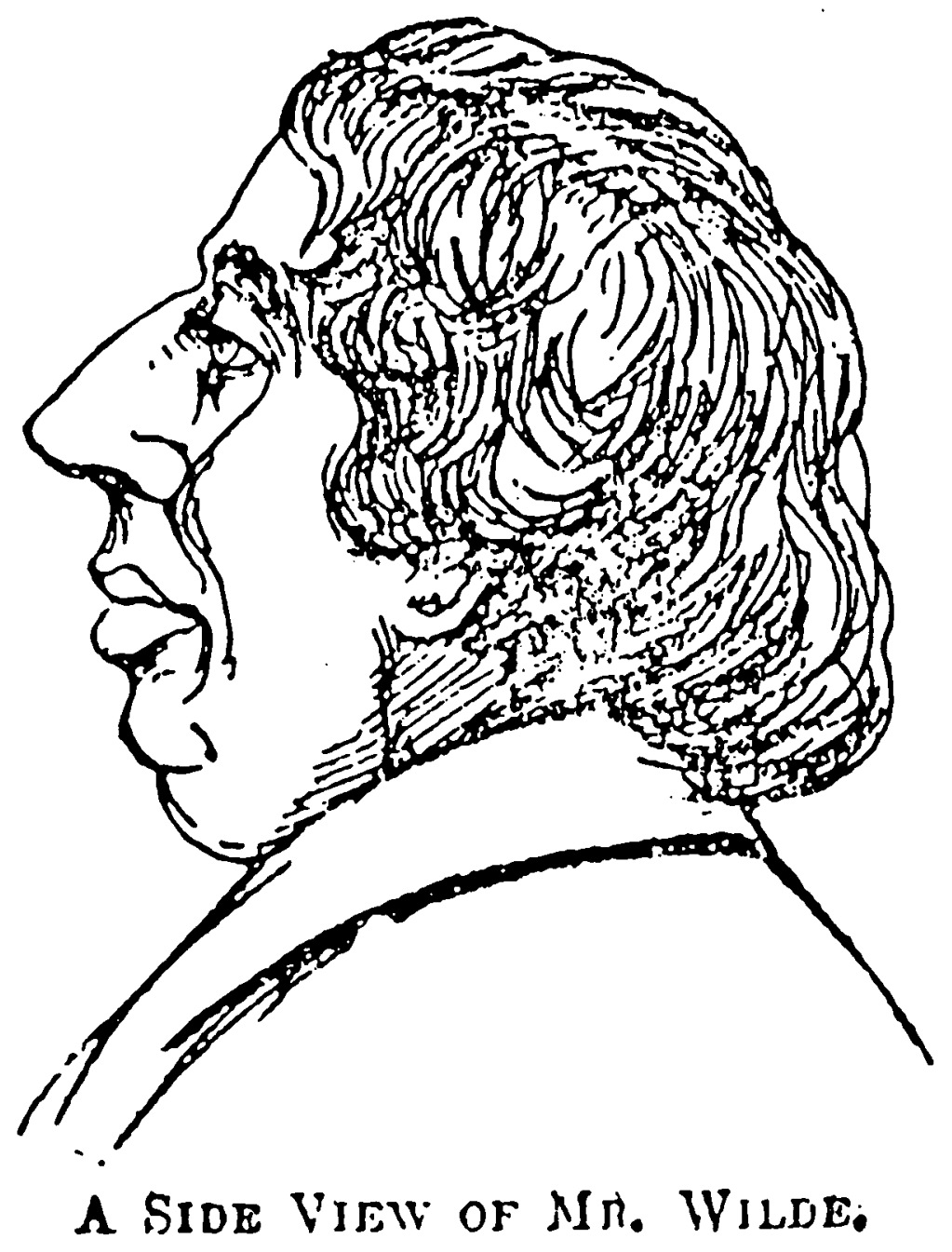

Figure 5. The Morning Leader, 4 April 1895. 

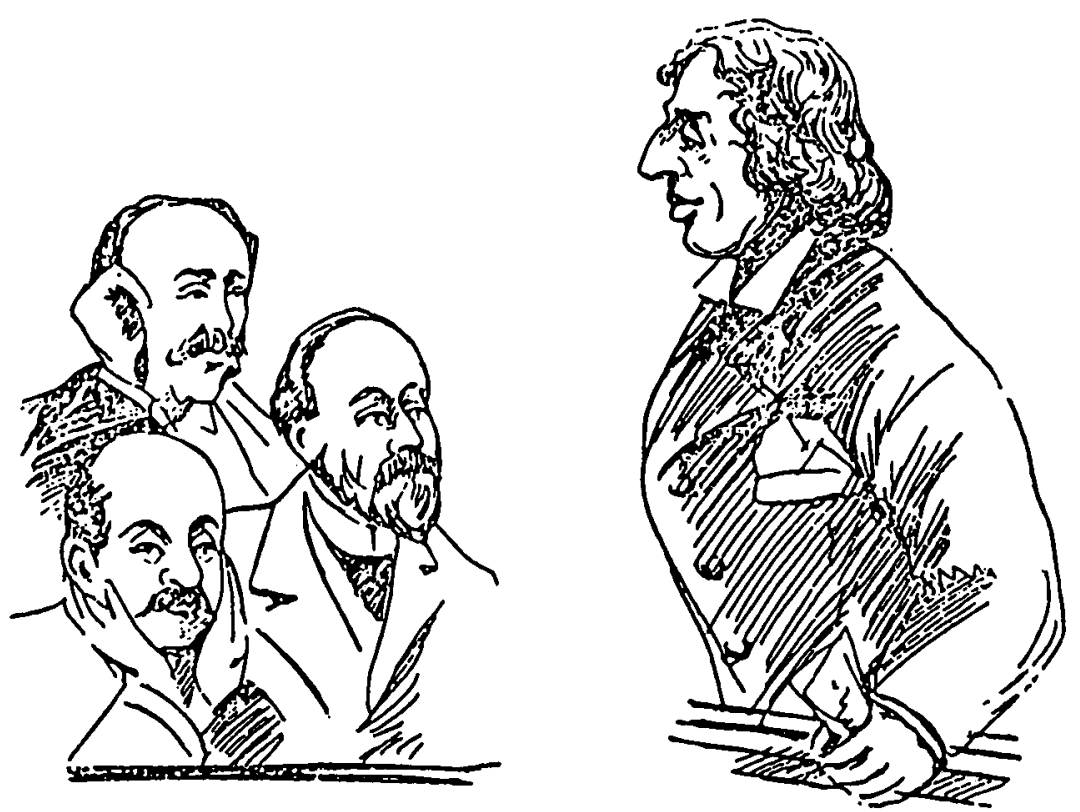

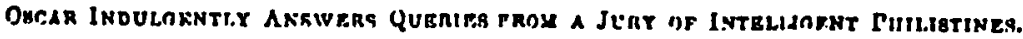

Figure 6. The Morning Leader, 5 April 1895.

male behavior onto their representations of these figures, thereby constituting these representations as confirmations of the "naturalness" of such difference.

As they embed the characterological opposition between the Marquis of Queensberry and Oscar Wilde in their narrative accounts of the trial, the newspapers inscribe this opposition in the determining action from which the journalistic "stories" ensue. Hence, the various depictions of the two men come both to personify the structures of difference through which the newspapers articulated their narratives and to represent the differences in question as the negation of middle-class male norms. Political theorist Ernesto Laclau has suggested that the construction of such dialectical contradictions, i.e., binary pairings taking the form " $\mathrm{A} / \mathrm{non}$ A" or here "norm/not-norm," provides one of the primary strategies through which hegemonic discourses recoup "real opposition" within the terms of dominance and therefore (re)produce hegemony itself. ${ }^{18}$ As such, he argues, this putative "oppositional" structure inheres in most of the cultural forms used to give shape to and engender meanings from the worlds in which we live. While at a general level this analysis offers an important insight into how certain values and practices are systemati-

18. Ernesto Laclau, "Populist Rupture and Discourse," Screen Education 34 (Spring 1980): 87. 93. 


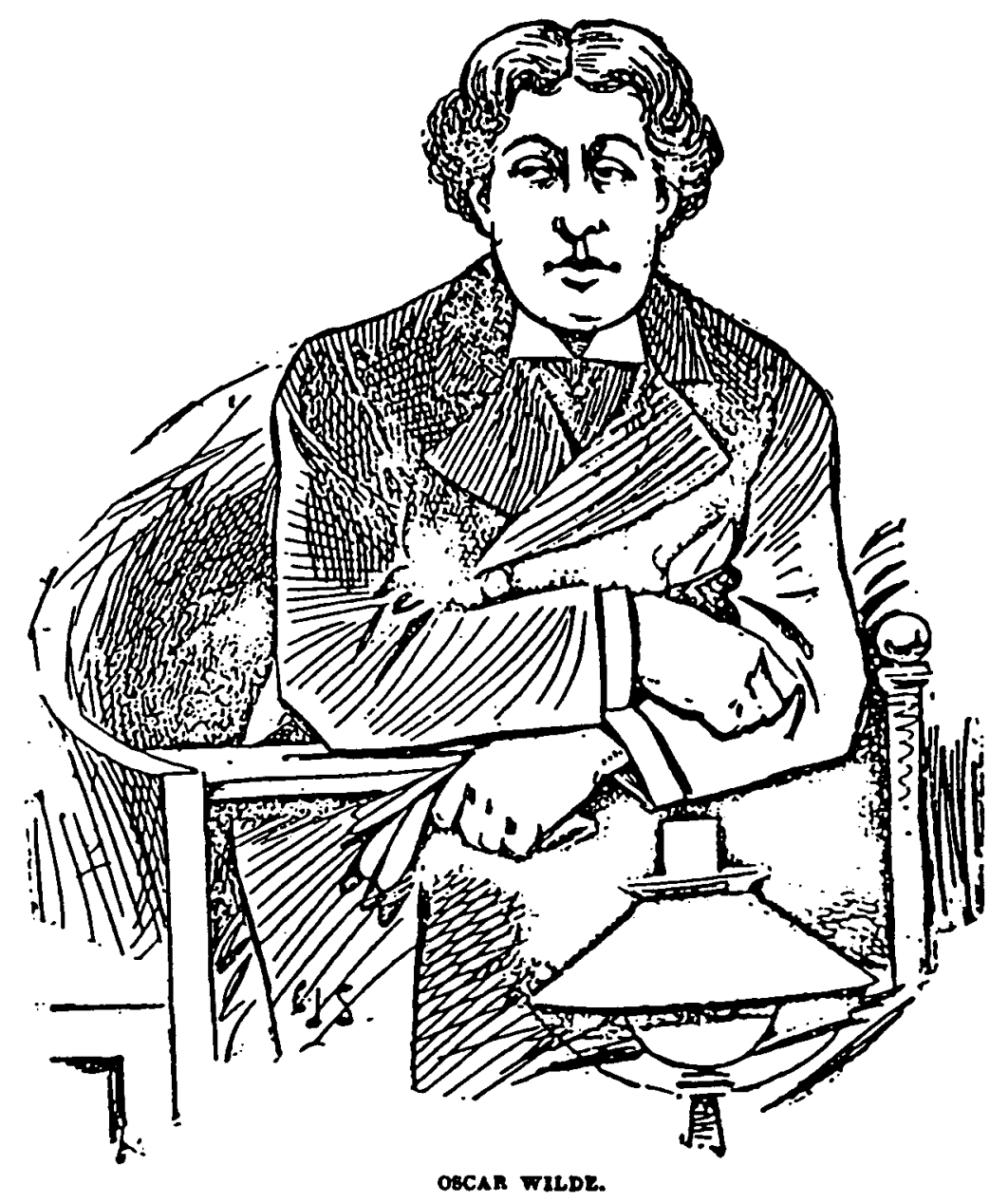

Figure 7. News of the World, 7 April 1895.

cally privileged over and against all others, in the reporting on Wilde $v$. Queensberry such a strategy took on a unique importance which made it pragmatically even more critical. Since the allegations made against Wilde both in the libel itself and in the subsequent "justification" were defined in the dominant representational codes of the period as being literally "unrepresentable," they therefore could not actually appear in print on the pages of the newspapers that purported to tell their story. Hence the possibility of signifying these allegations negatively as the absence of what was precisely most representable, i.e., the dominant norms, allowed the newspapers to circumvent those very representational strictures that would have otherwise rendered their coverage of the trial both unintelligible and unmarketable.

The need for this representational strategy necessarily emerged even as 
the newspapers sought to represent the case's opening, since the moment Sir Edward Clarke rose to indicate the grounds for the prosecution, he immediately introduced the journalistically forbidden word "sodomy" into the courtroom. Moreover, because the defense's plea of justification was constrained by the alleged libel to name "sodomy" repeatedly even while it simultaneously sought to abjure this increasingly anachronistic term in order to define a more diffuse sense of the sexual possibilities between men, it made sodomy's legal (re)articulation a central issue in the proceedings. The appearance of this unprintable word as the crux of the case confounded the unmediated movement between legal context and public (con)texts, forcing the newspapers to attempt to circumvent their representational limits by translating the legal utterance into printable terms. Indeed, as the trial unfolded and the defense assiduously sought to undermine Wilde's prosecution by alluding to supposed evidence of his intimate relations with young working-class men, the stakes in the gamble for linguistic respectability were markedly increased. So while the courtroom proceedings circled around the unarticulated implication that Wilde had sought the sexual services of the men named in the plea of justification, the newspapers were challenged to report this testimony without actually revealing any of its very titillating substance.

In struggling to negotiate this edge of social acceptability and yet retain the sexual implications that made the trial newsworthy-and indeed highly marketable - the newspapers necessarily developed a compensatory set of signifying practices to invoke the unprintable signifier without naming it directly. They thereby opened up an interpretive space outside the legal purview within which a new sense of male sexual behavior could emerge. ${ }^{19}$ For, in order to mitigate the semantic and commercial consequences that the exclusion of the word "sodomy" threatened to produce, the journalistic texts constructed a complex web of signifiers that endlessly deferred specifying the unnamed and unnameable accusations while explicitly denoting them as an absent site of signification that made their stories meaningful. In other words, they negatively characterized Wilde's behavior as "immoral," "immodest," "un natural," "im proper," "in decent," "un respectable," "disreputable," etc., in order to avoid having to specify positively the actual sexual acts named in Queensberry's defense. Instead, they portrayed Wilde's acts, and ultimately his "person," in terms of the overdetermined absence of those qualities that ideologically defined normative middle-class male behavior (e.g., "morality," "modesty," "nature," "propriety," "decency," "respectability," etc.). This representational configuration

19. The point here is not that the newspapers were original in their development and deployment of these strategies but rather that they crystallized the signifying practices that had heretofore been diffuse. While it is beyond the scope of this analysis to consider, it would be interesting to compare the journalistic strategies with those of less standardized popular genres. 
organized these highly evocative affirmations of bourgeois hegemony into an effective, gendered unity whose absence then indicated the presence of "unnameable" sexual acts. Hence, the newspapers represented the defense's suggestion that Wilde engaged in sexual relations with other men through a chain of signifiers that transformed these relations into the antithesis of the middle-class sexual norms for men and simultaneously produced "Oscar Wilde" as the metonymic embodiment of this chain.

The journalistic limits of enunciation, then, both excluded the mention of a signifier whose play had heretofore (re)produced the cultural/legal significance of sexual acts between men and simultaneously engendered a new configuration of signifying practices that would reorganize this (sexual) significance around that signifier's visible absence. Since the defense had similarly oriented its legal strategy around a verbal gesture that moved away from an actual invocation of "sodomy" while deploying its absence to motivate the notion of a type of individual who might be inclined to commit the "unnameable" act, the newspapers could both explicitly and implicitly incorporate the terms of this strategy into their representations of the case. By mediating between the defense interpretation and the popular limits for (sexual) representation, the newspapers reiterated the defense's attempts to construct a new category of sexual transgression that could be signified not by reference to specific "unnameable" sexual acts but by the depiction of a certain type of sexual actor.

Given this conjuncture of interpretive interests, it is not surprising that the inception of the newspaper narratives almost universally coincided with the textual shift from act to actor. Perhaps the most instructive example can be found in the Evening Standard which along with the Daily Telegraph and the Morning provided extensive daily coverage of the case. Beginning its story on 3 April with a detailed paraphrase of the prosecution's opening statement, the Standard represented both the libel's "unrepresentable" word and the fact of its unrepresentability by foregrounding the word's absence in the text.

The libel was published in the form of a card which was left by Lord Queensberry at a club to which Mr. Oscar Wilde belongs. It was a visiting card with the Marquess of Queensberry's name printed upon it, and also had written upon it the words, "Oscar Wilde posing as

As the paper mimics the publication of Queensberry's statement, it simultaneously censures the libel's proper name leaving only a blank as the mark of its excisement. Therefore the blank enters the journalistic text as the organizing principle of the narrative: it is the space occupied by the offensive signifier that motivates Wilde's legal action, the ostensi- 
ble "subject" of the story, and yet it remains mute. Instead, Wilde's name alone serves as the site of meaning here so that it is invested with the trace of something that has been suppressed; something potentially libelous; indeed, something so potentially libelous as to warrant an article comprising five columns of a special edition's front page. The article then goes on to report Clarke's characterization of the suppressed word directly:

Of course, it is a matter of serious moment that such a word as Lord Queensberry had written should be in any way connected with the name of a gentleman who has borne a high reputation in this country.

Pointing to the blank as a particular type of utterance ("such a word"), the paraphrase indicates that the missing word is not just any word, but a word with power: the power to threaten "a gentleman," even one "who has borne a high reputation in this country." This gloss reveals the word-not-written as a nexus for language, class, nationality, sexuality, and social status-if only through its ability to radically disrupt these connections. Now, however, since the blank space's indeterminacy threatens to rend the textual/sexual fabric entirely, the newspaper account attempts to contain the damage by suturing the gap paraleptically:

It is not an accusation of the gravest offense. "Posing as _-" indeed appears to suggest that there was not guilt of the actual offense, but that in some way or other the person of whom the words are written has appeared to be, indeed desired to appear to be, a person guilty of or inclined to the commission of that gravest of all offenses.

The text's negative construction, "not . . . the gravest offense," indicates that indeed the "gravest offense" is precisely at issue. Displaced from the literal statement of the libel, the phrases "gravest offense" and "actual offense" become paradigmatic equivalents for the suppressed signifier, even as the "__ qualifies this relationship. No longer a strict negation or suppression, the quotation shifts the text's focus from the "offense" to a "person ... [who] appeared to be, indeed desired to appear to be, a person guilty of or inclined to the commission of that gravest of all offenses." That is, it shifts the concern from the act to the actor.

This shift is even more marked in the reports provided by the Echo, the Times, the Star, the Morning Leader, the Evening News, and the Daily Telegraph, where the entire phrasing of the libel is effaced from the text, so that Wilde as sexual actor becomes the only concrete referent for the alleged act.

The libel was published in the form of a card that was left by Lord Queensberry at a club to which Mr. Oscar Wilde belongs. It was a 
visiting card with the Marquis of Queensberry's name printed upon it. Of course, it is a matter of serious moment that such a word as Lord Queensberry had written should be in any way connected with the name of a gentleman who has borne a high reputation in this country. (Daily Telegraph)

In opening the case for the prosecution, Sir Edward Clarke pointed out the enormous gravity of the accusation leveled against Mr. Wilde by the Marquis of Queensberry. But the defendant's plea raised a much graver issue, for in that plea it was alleged that the complainant had solicited various persons to commit an offense. (Echo)

It was a visiting card of Lord Queensberry with his name printed upon it, and it had written upon it certain words which formed the libel complained of. In respect of that libel so published, this charge was brought against the defendant. Of course it was a matter of serious moment that such a libel as Lord Queensberry had written upon that card should be in any way connected with the name of a gentleman who had borne a high reputation in this country. The words of the libel were not directly an accusation of the gravest of all offenses-the suggestion was that there was no guilt of the actual offense, but that in some way or other the person of whom the words were written did appear-nay, desired to appear and pose to be a person inclined to the commission of that gravest of all offenses. (Times)

Sir Edward Clarke at once rose and began the case. He told how the Marquis called at the Albemarle Club and left a card "To Oscar Wilde," which contained words that were gross and libelous. The accusation against Mr. Wilde was one of the gravest that could be made. But the card was not the only matter with which they would have to deal. By the plea put before the court a much graver issue was raised. There was no accusation in the plea that Mr. Oscar Wilde had been guilty of a criminal offense, but there were given the names of a number of persons whom he was accused of inciting to commit such offenses and with whom he was charged with improper conduct. (Evening News)

Sir Edward Clarke plunged at once in medias res. He first read to the jury the card which Lord Queensberry left open with the porter of the Albemarle Club for the plaintiff-containing a very grave allegation against Mr. Wilde's character-and pointed out that it seemed to stop short of actually charging the plaintiff with the commission of one of the most serious offenses. By the plea which the defendant had put before the court a much graver issue was raised. (Star; the Morning Leader copied this account verbatim in its report the next morning)

Here the texts both signal that the card was read into testimony and that this reading was beyond the scope of journalistic representability. How- 
ever, unlike the Evening Standard, the Morning, and Lloyd's Weekly Newspaper where the libel's "unrepresentability" was represented by the marked absence of a single, specific word, these papers instead euphemistically render the contested statement by underscoring-in the Echo's phrase- "the enormous gravity of the accusation." Indeed, the Star and the Morning Leader graphically highlight the suggestion that Queensberry's allegation was beyond the limits of public discourse by confining even their incredibly vague paraphrase of the libel, "a very grave allegation against Mr. Wilde's character," within the textual quarantine of hyphens. Thus, these texts symbolically presented the "allegation" as "unrepresentable," while simultaneously juxtaposing the unarticulated statement to what the Times refers to as "the gravest of all offenses," or as the Star's less superlative diction names it, "one of the most serious offenses." That the texts turn around the "gravity" of the unnamed "offense" illustrates the way in which the newspapers actively thematize the Marquis of Queensberry's imputations against Wilde as the case's pivotal (signifying) moment, constituting them as of more importance than Wilde's contention that he had been maligned which (almost ironically) formed the actual legal basis for the case. This journalistic identification with Queensberry's interpretive position, reiterated in the Echo, the Morning Leader, and the Star, which all emphatically insist that the charges made in the plea of justification constituted a "much graver issue," signals these newspapers' concern not simply with the unnamed offense (sodomy) but with the suggestion that Wilde, in the Times rhetoric, "desired to appear and pose to be a person inclined to the commission of that gravest of all offenses."

By constituting Wilde's "pose" as the crux of the narrative, the ensuing descriptions of Sir Edward Clarke's opening statement foreground the interpretation of Wilde's words-and not Queensberry's-as the site of contested meaning. Although in his statement to the court Clarke undoubtedly attempted to provide an account of Wilde's background and to develop a story that could explain his relationship with Alfred Douglas in nonincriminating terms, the newspapers represented this attempt by focusing on those aspects of the statement that were most evocative and hence most incriminating. Thus, while the actual specifics of the statement that appeared in any particular paper varied widely-ranging from the Evening Standard's obsessively detailed paraphrases to the Times's summary sentences-all the dailies were consistent in their emphasis on reporting an attempt to blackmail Wilde for a letter he wrote to Douglas. In part, this emphasis can be seen to derive from the cultural connotations already associated with the criminalization of sexual relations between men: as $\mathrm{H}$. Montgomery Hyde has suggested, by the time of the trial, and indeed even at the moment of its passage, section 11 of the Criminal Law Amendment Act had been dubbed "the 
Blackmailers' Charter."20 Yet even more important than the general implications ascribed to blackmail were the particular meanings attributed to the text that was the subject of the blackmail attempt: a "letter" from Wilde to Alfred Douglas, according to the defense; a "prose poem," from an established author to an acolyte, according to the prosecution.

The story of the blackmail was first introduced to the court by Wilde's counsel who apparently sought to preempt the defense's ability to interpret the suggestive correspondence as sexually incriminating. His statement thus carefully situates the text itself within a narrative frame that tries to undermine the assumption that because Wilde was being blackmailed he had something to hide and simultaneously to introduce a competing literary as opposed to sexual standard for interpreting the writing in question. Since the Evening Standard (3 April) provides the most meticulously detailed reporting of this prosecution tactic, it is worth quoting here at length both in order to present the outlines of Clarke's narration and to illustrate the way in which it was taken up by the press:

In the early part of 1894 [sic] Mr. Wilde became aware that certain statements were being made against his character. He became aware in this way. There was a man named Wood, who having been given some clothes by Lord Alfred Douglas, and who said that he had found in the pocket of a coat four letters written by Mr. Wilde to Lord Alfred. Wood came to Wilde early in 1893, and wanted him to give him something for the letters, representing that he was in great distress and wanted to go to America, and Mr. Wilde gave him $£ 15$ or $£ 20$ in order to pay his passage. Wood thereupon

20. H. Montgomery Hyde, The Trials of Oscar Wilde (New York: Dover, 1962), 12. Hyde's book on the trials is the only text published within the last fifty years to treat the trials as its primary concern. The absence of information on Wilde's trials seems a serious omission not only for the emerging historical genres of gay or sexual history but also for the more canonical study of legal history as well. In fact, it was as legal history that Hyde's book initially appeared, constituting one work in a "Famous Trials" series, as did the only other book on the trials, Oscar Wilde: Three Times Tried (London: Ferrestone Press, 1912), by Stuart Mason (Christopher Millard), which appeared anonymously in a series of "Great Trials of the Nineteenth Century." The only other work to focus exclusively on the trials (but only the second and third trials) is another monograph entitled "The Trials of Oscar Wilde-From the Shorthand Reports" by Charles Carrington and printed privately in Paris in 1906 (actually the text is not taken from shorthand reports, but-as with all of the works on the subject-derives from compilations and/or abstractions from the newspaper clippings on the trials).

Because Hyde's works have been the primary source for nearly all contemporary narratives about Wilde's trials and conviction-having presented his account almost without variation in The Trials of Oscar Wilde, Oscar Wilde: A Biography, Oscar Wilde: The Aftermath, The Other Love (or, as its American pressing is entitled, The Love that Dared Not Speak Its Name), Cases That Changed the Law, and his recently published biography of Lord Alfred Douglas-his interpretation of what he characterizes as Wilde's "downfall" has provided and effectively continues to provide a de facto "official version" of the case.

Richard Ellman's much-acclaimed recent biography of Wilde repeats Hyde's "tragic" structure exactly, as the book's section headings confirm: "Beginnings," "Advances," "Exaltations," "Disgrace," "Exile." For an analysis of the problems with this structure, see my "Nothing Wilde," The Nation 246.6 (1988). For a detailed "ideological" reading of Hyde's text, see my "Hyding Wilde," Talk on the Wilde Side: Towards a Genealogy of the Discourse on Male (Homo)Sexuality (Ph.D. diss., Stanford University, 1989), 1-40. 
handed over to him the somewhat ordinary letters that had been written by him to Lord Alfred, but, as generally happens when people think they have letters of some importance, the letters of no importance are given up, and that which is supposed to be of importance is retained. That was the case in this instance. In $1893 \mathrm{Mr}$. Wilde's play $\boldsymbol{A}$ Woman of No Importance was being prepared for production at the Haymarket Theatre, and there came into the hands of Mr. Beerbohm Tree, the actor and manager, a piece of paper which purported to be, and to some extent was, a copy of the letter which had been retained by Wood and two men named Allen and Clyburn. On it was written, "Kindly give this to Mr. Oscar Wilde and oblige." Shortly afterwards Allen called on Mr. Wilde and said that he had the original letter and wanted him to give him something for it. Mr. Wilde absolutely and peremptorily refused, saying, "I have a copy of that letter and the original is of no use to me. I look upon it as a work of art. I should have desired to possess a copy; now you have been good enough to send me a copy, I do not want the original." He sent Allen away, giving him a sovereign for himself, and almost immediately afterwards Clyburn came and said that Allen so appreciated his kindness that he sent back the letter. He handed over the letter, and Mr. Wilde gave him a sovereign for his trouble. Having once got the original letter in his possession, Mr. Wilde kept it, and it is in my hands now. He said then, and he says now, that he looks upon it as a sort of prose sonnet. He told Allen that it would probably appear in sonnet form, and on May 4, 1893, a publication was issued, called the Spirit Lamp, an aesthetic, literary and critical magazine edited by Lord Alfred Douglas, and on the first page was a sonnet in French described as "A letter written in prose poetry by Oscar Wilde to a friend, and translated into rhymed poetry by a poet of no importance." It was not an exact reproduction but a paraphrase of the letter. Here is the letter:"My own boy. Your sonnet is quite lovely, and it is a marvel that those red rose-leaf lips of yours should have been made no less for music of song than for madness of kisses. Your slim gilt soul walks between passion and poetry. I know Hyacinthus, whom Apollo loved so madly, was you in Greek days. Why are you alone in London, and when do you go to Salisbury? Do go there to cool your hands in the gray twilight of Gothic things, and come here whenever you like. It is a lovely place-it only lacks you; but go to Salisbury first.-Always with undying love, Yours, OSCAR."

While it is no longer possible to ascertain the "factual accuracy" of this reported version, in the context of the courtroom this story (however it was first spoken) obviously had significantly different rhetorical and semantic effects than its journalistic counterpart. There the tale appeared in the flow of an opening statement designed to establish the legal grounds for the prosecution and at the same time to mitigate any foreseeable objections portended by the defense's plea of justification; 
here, bereft of both its persuasive intention and effect, the story merely provides anecdotal detail that underscores the representation of Wilde as a character who exists at and is familiar with the margins of respectable society. Shifting abruptly from a focus on Wilde's relations with the Douglas family (rendered in indirect discourse) to what is obviously meant to be taken as a verbatim account of Clarke's speech, the newspaper text rhetorically distinguishes the blackmail story from what precedes it: a change in narrative mode foregrounds the "significance" of the reported material, while the heightened sense of "realism"-produced in part by an embedded quotation appearing in Wilde's own "voice" as well as by the distinctive style of the letter itself-concomitantly evokes the "fictional" expectation that these bits of dialogue can be read as character development. By revealing Wilde as a social actor who not only repeatedly engaged with and ultimately paid off Wood, Allen, and Clyburn but who was also prepared to legitimate his writing to them as "a work of art," the Standard's account implicitly juxtaposes the incriminating interpretations presupposed by the blackmail scene to their subsequent justification in the courtroom. Thus inserted in the "diagesis" of the courtroom narrative, the quotation of Wilde's letter constitutes his writing as a critical site for the trial's struggle over meanings even as it illustrates the symbolic function of the letter as an index of Wilde's character.

In reporting Clarke's gloss on Wilde's "prose poem," then, the newspapers establish a homology between textual interpretation and characterological assessment. For as Wilde's words are subjected to rigorous scrutiny by both the prosecution and the defense, they form the basis for a slippage between textual meaning and authorial intention so that the imputations made against the former (in the courtroom) will become (in the press) evidence against the latter. Thus, although the prosecution sought to introduce the question of "literary" meaning(s) in order to circumvent the monologic effects of legal interpretation and thereby interrupt the defense's ascription of "unnatural and sodomitical" significance to Wilde's texts, the representation of this strategy in a journalistic (con)text provided the opportunity for underscoring these writings as inherently sexualized. Since the blackmail letter was the first such text introduced in the case, it provides the initial occasion for articulating this connection.

The words of that letter appear extravagant to those who are in the habit of writing commercial correspondence (laughter), or those ordinary things which the necessities of life force upon one every day, but Mr. Wilde says that it is a prose sonnet, and one that he is in no way ashamed of, is prepared to produce anywhere as the expression of a poetical feeling, and with no relation whatever to the 
hateful suggestions put to it in the plea in this case. (Evening Standard, 3 April)

The words of that communication, Sir Edward Clarke continued, might seem extravagant to their more prosaic and commercial experiences, but Mr. Wilde was a poet, and the letter was considered by him as a prose sonnet, and as an expression of true poetic feeling, and had no relation to the hateful and repulsive suggestions incorporated in the plea in this case. (Times, 4 April)

This [letter], said Sir Edward, might seem extravagant to those who were in the habit of commercial correspondence-(Great laughter in which Mr. Oscar Wilde joined)-but it was merely poetry, not indicative of crime, maintained Sir Edward in effect. (Pall Mall Gazette, 3 April)

When Sir Edward Clarke read this letter there was a momentary and involuntary outburst of merriment. Sir Edward said it might provoke mirth in those used only to commercial correspondence, but Mr. Wilde denied that it was open to any unclean interpretation, or was more than the letter of one poet to another. (Star, 3 April; repeated verbatim in Reynolds's, 7 April)

By juxtaposing the "prosaic" realm of "commercial" correspondence to the "poetical feeling" evoked by Wilde's letter, these quotations signal the prosecution's attempt to define the "poetic" as a privileged source of significance that transcends "everyday" meaning. Yet since the newspapers are the medium of "commercial correspondence" par excellence, selling precisely those "ordinary things which the necessities of life force upon one every day" as "news," the narrative apparatus's epistemological and financial interests immediately undermine the claims to legitimacy that this "aesthetic" ideology propounds. Here the attempts to interpolate "courtroom" laughter into the otherwise strictly verbal accounts foreground the friction created when the prosecution's utterance appears in different (con)texts: what appears in the Old Bailey chambers as a joke about the insufficiency of a restrictive hermeneutic, provoking, according to the Pall Mall Gazette, "[g]reat laughter in which Mr. Oscar Wilde joined," becomes in the other journalistic transcriptions an indication of the absurdity of such an interpretation. (Note how the Star makes the letter itself and not Clarke's comment the catalyst for the mirthful moment.) In other words, through the dual journalistic processes of de- and re-contextualization, Wilde comes to be identified as the "poet" whose language moves athwart those mundane linguistic conventions that delimit the standard idiom (here variously opposed to "unclean," "hateful," "repulsive," or "criminal" usage) in which the newspaper reader is immediately engaged. Thus, while what is legally at stake in the letter's interpretation is whether or not it corroborated the Marquis of Queensberry's statement that Wilde was "posing as a sodom- 
ite," the journalistic (con)texts transform this interpretation by situating it in a narrative that identifies Wilde-both as writer and as sexual actor-as the sole locus of meaning.

The newspapers reiterate this identification on a more generic level when they take up Clarke's response to the defense allegations made against Wilde's published works in the plea of justification, allegations that in turn become the crux for the defense's vituperative cross-examination of Wilde. For, as they report Clarke's attempt to deny the sexual interpretations attributed to Wilde's writings, the journalistic accounts actually underscore the equation that Queensberry's solicitors sought to effect between Wilde's writing and his "character."

There are two counts at the end of this plea that are extremely curious. It is said that in the month of July $1890, \mathrm{Mr}$. Wilde published, or caused to be published with his name upon the title page, a certain immoral and indecent work, with the title "The Picture of Dorian Gray" which is intended to be understood by the readers to describe the relations, intimacies, and passions of certain persons guilty of unnatural practices, and that in December 1894, was published a certain immoral work in the form of The Chameleon, relating to practices and passions of persons of unnatural habits. . . . These are two very gross allegations. Why they are added I can hardly imagine unless my learned friends . . . intend to suggest to you that if all the other evidence fails $\mathrm{Mr}$. Wilde should be treated by you as a person inclined to certain practices because he published The Chameleon and "The Picture of Dorian Gray." ... [B]ut I shall be amazed if my learned friend can get from this anything that in the remotest degree suggests anything hostile to the character of $\mathrm{Mr}$. Wilde. (Evening Standard, 3 April)

There are two allegations at the end of this plea that are extremely curious. It is said that in the month of July 1890, Mr. Wilde published, or caused to be published with his name upon the title page, a certain immoral and indecent work, with the title "The Picture of Dorian Gray" which is intended to be understood by the readers to describe the relations, intimacies, and passions of certain persons guilty of vice and that in December 1894 was published a certain immoral work in the form of a magazine called "The Chameleon." ... These are two curious allegations. Why they are added I can hardly imagine unless my learned friends ... intend to suggest that if all the other evidence fails Mr. Wilde should be treated by you as a person inclined to certain practices because he published "The Chameleon" and "The Picture of Dorian Gray" ... but I shall be amazed if my learned friend can get from this anything that in the remotest degree suggests anything hostile to the moral character of Mr. Wilde. (Daily Telegraph, 4 April)

He [Sir Edward Clarke] would do nothing to extend the range of the case beyond the radius which was inevitable. But two of the allega- 
tions were so strange that he was bound to notice them. The first was that in July 1890, Mr. Wilde published a "certain immoral and obscene work entitled 'The Picture of Dorian Gray,' designed and intended to describe the relations, intimacies and passions of certain persons of unnatural habits, tastes and practices." The second was that in December 1894 he published a "certain other immoral and obscene work in the form of a magazine entitled The Chameleon," containing similar references and "certain immoral maxims entitled 'Phrases and Philosophies for the Use of the Young.' " (Star, 3 April)

He [Sir Edward Clarke] did not intend to mention the names alluded to in the pleadings, but he would deal with certain suggestions made in those pleadings that Mr. Wilde was the writer, or at all events the publisher, of articles of a remarkable and unnatural tendency. One of the publications called in question was the "Picture of Dorian Gray," a book that, strangely enough, had been publicly sold for several years. The learned counsel outlined the story, and defied the other side to prove that the author had done more than use a novelist's privilege to portray the vices and passions of human nature. (Echo, 3 April)

In the accounts appearing in the Evening Standard, the Daily Telegraph, and the Star, Clarke's quotations from the plea of justification are almost reported verbatim with the crucial exception that the words used to describe the text's "sexual characteristics" explicitly there are rendered euphemistically here. Yet unlike the initial descriptions of the defense allegations against Wilde himself, which by and large represented the original legal language through the complex structure of mediation discussed above, these versions follow the syntax of the defense pleading exactly with only tactical omission (e.g., the word "sodomitical" in the Standard) or substitution (e.g., the word "vice" in the Telegraph). The emergence of this manifestly legal formulation into texts that had heretofore abjured such explicit expression calls attention both to the ostensible subject of the statement (i.e., Wilde's writings) and to the imputations made against them $/ \mathrm{him}$. This attention becomes especially critical when the repetition of the phrase "the relations, intimacies, and passions of certain persons guilty of unnatural practices" (or "vice") as a description of Wilde's texts becomes the precursor for the corollary suggestion that this interpretation casts Wilde as "a person inclined to certain practices." While in the course of his statement Sir Edward Clarke was obviously attempting to interrupt this defense equation between Wilde's writings and his "character," the reports of his argument seem to create the opposite effect in the press: by representing Clarke's denial of the defense's interpretations, the newspapers transform it into the very means of introducing these interpretations to a reading public that had no other access to them. As the paraphrase of the defense position provided by the Echo 
suggests, "a remarkable and unnatural tendency" comes as easily to describe Wilde's "character" as it does his texts, thereby constituting these writings as a primary locus for publicly defining his sexual identification.

Having just rendered Clarke's statement for the prosecution in terms of -or more accurately, as the negation of-the defense's attempt to establish a (sexualized) equivalence between writer and text, the papers then turn to their depictions of Wilde's appearance as the primary witness which followed immediately upon the conclusion of the opening statement. While in the courtroom this movement was part of the trial's flow and as such was punctuated by numerous spatial and temporal gestures that marked these out as distinct moments, in the journalistic representations their immediate juxtaposition necessarily works against Wilde since the accounts of his entrance into the witness box appear to confirm Queensberry's characterization of him. As with the opening statement, this textual formulation was to some extent determined by the prosecution itself, since the apparent purpose of Wilde's testimony was to preempt the defense's ability to define his actions (both physical and verbal) as sexually transgressive. Appearing in the box on his own behalf, Wilde was led through a series of questions that allowed him to recount in his own uniquely flamboyant style the "story" of his harassment by the Marquis of Queensberry. While much of the narrative had been outlined by Sir Edward Clarke in his opening address to the court, Wilde's reiteration was not simply designed to underscore the gravity of the allegations, but rather sought to co-opt the defense's characterization of Wilde by establishing a more compelling counterinterpretation in his own voice. In this struggle for meanings, the deployment of Wilde's ability as a storyteller proved to be the most powerful resource-even if it was not ultimately a persuasive one-for the prosecution, and the force of his narration came to organize the journalistic accounts of his testimony.

Beginning with a short catechism designed to establish him as a scholar, author, popular playwright, husband, and father, Wilde's direct examination consisted primarily of a series of interlocking anecdotes that circled back upon and then extrapolated from the question of blackmail introduced in the opening statement. But since the details of the blackmail scheme had already been largely laid out, it was Wilde's rendering of them and not the "facts" themselves that constituted their newsworthiness. As the Morning notes in its commentary on his testimony, Wilde's self-(re)presentation was really the focus of journalistic attention:

He answered the friendly questions addressed to him in a modulated voice, though his affected manner rendered his replies rather difficult to catch. During that portion of his examination which treated of the interviews he had with three men regarding the letters sent by him to Lord Alfred Douglas, Mr. Wilde asked for and obtained per- 
mission to explain in his own way exactly what took place. With eyes fixed on the ceiling and in a deliberate style, he narrated with remarkable precision the exact words used on the occasion. (5 April)

In reflecting on Wilde's appearance as a witness, the Morning constructs an opposition between Wilde's verbal self-control (i.e., his "modulated voice") and his (re)presentational style (i.e., his "affected manner") noting that the latter undermined the public comprehension of the former. The report then compounds the implications attributed to this contradictory effect by indicating that Wilde's narration comes to occupy a unique, (self-)identifying positioning in the courtroom, thereby conspicuously foregrounding the relation between his words and his person. That his distracted gaze is conjoined with his "deliberate style" to signify the point of origin of his "remarkably precise narration" underscores the extent to which Wilde's verbal effect comes to represent-and indeed (re)produce-his "character." Thus, in depicting Wilde's testimony the newspaper implicitly suggests a way of reading his words so that they come to signify not just semantically but also behaviorally: that is, they begin to identify him as a complex source of meaning that can then be understood (or interpreted) as a particular kind of (sexual) person.

Since the fascination with Wilde's verbal talent was so central to the public interest in the trial-and rightly so, as his performance in the box was an incredible tour de force-it is not surprising that it should figure prominently in almost all the accounts of the case. The Daily Telegraph and the Evening Standard, for example, provided what appear to be largely unedited versions of the examination process detailing both Wilde's tale and the manner of its telling. These reports are textually constructed as dramatic dialogues between the witness and his counsel so that the dynamics of their interaction emphasize the power of Wilde's wit in contrast to his interlocutor's staid legal language. Since the efficacy of Wilde's unmediated verbal skill is legendary and since the depiction of his lengthy testimony is foregrounded in H. Montgomery Hyde's treatment of the case, it seems more profitable here, for the sake of brevity, to consider the effect of Wilde's language when it is not explicitly showcased-or, indeed, when it is manifestly constrained-in order to illustrate the extent to which his representation as a "speaking subject" came to be understood as "characteristic."21 As the following extract from the Times (5 April) suggests, the capacity of Wilde's narration to interrupt

21. While it is far beyond the scope of this article to consider the social and historical construction of contemporary psychoanalytic categories, it does seem interesting to note in passing that Wilde's initial representation as a sexual subject by the press was organized around the question of his language to the extent that it bore the trace of his (unnameable) sexual practices. This implicit privileging of the relation between linguistic utterance and sexual desire suggests that the conceptualization of "the sexual" was undergoing a larger cultural transformation isomorphic to the shift from "activity" to "agency" precisely at the moment that Freud was beginning to hypothesize 
even the most powerfully monologic textual strategies became a primary index for his "personality."

In April 1893, Mr. Beerbohm Tree handed the witness what purported to be a copy of a letter. A man named Allen subsequently called upon the witness, who felt that Allen was a man who wanted money from him, and he said, "I suppose you have come about my beautiful letter to Lord Alfred Douglas. If you had not been so foolish as to send a copy to Mr. Beerbohm Tree I should have been very glad to pay you a large sum for the letter as I consider that it is a work of art." Allen said a curious construction could be put on the letter. The witness said, in reply, "Art is rarely intelligible to the criminal classes." Allen said, "A man had offered me $£ 60$ for it." Witness said, "If you take my advice you will go to him and sell my letter to him for $\mathbf{f 6 0}$. I myself have never received so large a sum for any prose work of that length, but I am glad to find that there is someone in England who will pay such a large sum for a letter of mine." Allen said that the man was out of town. The witness said that the man would come back, and added, "I assure you on my word of honour that I shall pay nothing for the letter." Allen, changing his manner, said he had not a single penny and was very poor, and that he had been on many occasions trying to find the witness to talk about the letter. Witness said that he could not guarantee his cab expenses, but handed him half a sovereign. Witness said to Allen, "The letter will be shortly published as a sonnet in a delightful magazine, and I will send you a copy." That letter was the basis of a sonnet which was published in French in the Spirit Lamp in 1893. Allen went away. About five or six minutes after a man called Clyburn came in. Witness said to him, "I cannot be bothered anymore about the letter. I don't care twopence about it." Clyburn said, "Allen has asked me to give it back to you." Witness said, "Why does he give it me back?" Clyburn said, "Well, he says that you were kind to him, and that there is no use trying to rent you, as you only laugh at us." Witness looked at the letter, and seeing that it was extremely soiled said, "I think it unpardonable that better care was not taken of an original letter of mine." He said he was very sorry - it had been in so many hands. Witness took the letter then and said, "Well, I will accept the letter back, and you can thank Mr. Allen from me for all the care he has shown about the letter." He gave Clyburn half-a-sovereign for his trouble. Witness said, "I am afraid you are leading a wonderfully wicked life." He replied, "There is good and bad in every one of us." Witness told him he was a born philosopher.

Here the Times's homogenizing prose style attempts to contain Wilde's dialogic testimony within its standard rhetoric for trial reporting. Thus,

this connection in a clinical setting with his work on hysteria (e.g., Studies in Hysteria was published in 1895 - the year of Wilde's trials). 
Wilde's name is effaced behind the generic designation "Witness" and his plurivocal narrative style is rendered as a patchwork of direct and indirect discourse. Yet in spite of the power of these rhetorical strategies to (re)produce the effects of a quasi-official documentation (in which the authority of the court is inscribed and legitimated in the very language of the reporting), the humor and the eloquence of Wilde's speech cannot be entirely circumscribed. In this passage, the juxtaposition of selected quotations from Wilde's testimony to the "standard prose" paraphrases (translations?) of the nonquoted portions underscores both the particularity of Wilde's style and its "difference" from official language. Foregrounding the facility of his wit, the use of direct discourse illustrates how Wilde sought both to recast the question of the letter's economic value in aesthetic terms ("I consider that it is a work of art"), thus challenging the sexual assumptions presupposed by the blackmail scene ("a very curious construction could be put on the letter"), and to humorously undermine the legitimacy of these sexual implications by insinuating that the blackmailers are not proper interpreters ("Art is rarely intelligible to the criminal classes"). However, since the effect of Wilde's humor is predicated on a self-referential display of linguistic prowess that continually calls attention to its own uniqueness (here in opposition to Clyburn and Allen and, in an ensuing anecdote, to the Marquis of Queensberry himself), its journalistic representation ironically seems to confirm the defense suggestion that Wilde's language is an indicator of his personal (sexual) difference.

While this imbrication of Wilde's linguistic and sexual difference remains implicit in most of the accounts of his direct examination, it is made strikingly explicit as soon as the papers begin to narrate his crossexamination by defense barrister, Edward Carson. Indeed, since Carson went to great lengths to prove the defense contention that there was an identity created between Wilde's sexual and literary "tendencies," it is not surprising that the journalistic representations of his cross-examination thematized this "identity" as Wilde's own "tendency." As the lead paragraphs of the Evening News's second day of coverage suggest, Carson's questioning not only constituted the climax of the dramatic events-or at least of their "dramatic" representation-but also "revealed" as any good story should the "true nature" of Wilde's "character."

Today was the second day of the hearing of the prosecution of the Marquis of Queensberry for criminal libel by Oscar Fingal O'Flahertie Wilde. The accounts of the first day's proceedings had generated tremendous interest. "I never write anything that is not extraordinary," Oscar had said in the witness-box and in addition to his extraordinary writings, the extraordinary character of some of his doings, as related by himself under cross-examination, had been 
"highly stimulative to thought," and had brought crowding into the Old Bailey corridors a bigger press of would-be hearers than ever.

The fame of yesterday's performance-it was little else-had gone abroad, the accounts of the strange attitude adopted by this "lover of things beautiful," who thinks "books cannot be moral or immoral," and who is "not concerned to do good or evil but only to create the beautiful," had excited no less interest than the reports of the wonderful intellectual force and flow of perfect language with which he defended his positions, and the curious tone of his epistolary prose sonnets, and the bizarre nature of his choice of chance acquaintances, had aroused a deeper interest still, which was mirrored in the packed court that patiently awaited the resumption of the trial, in which this strange personality is nominally accusing a relentless pursuer of libel, but is actually defending himself against one of the gravest charges that can be brought against an English gentleman. (4 April)

The progression of meanings outlined in these paragraphs illustrates precisely those connections between Wilde's "extraordinary writings" and "the extraordinary character of some of his doings" and his "strange personality" that the defense took pains to produce in the trial. Appearing under the heading "OSCAR TODAY" and interrupted by a crude line drawing depicting "Mr. Oscar Wilde" (see figure 8), this account quickly establishes "Oscar" as the point of reference from which the meanings ascribed to the "performance" must be drawn. By stringing together quotations from Wilde's epigrammatic replies to Carson's questionsquotations that are then reiterated at length in a feature following the "story" itself entitled "Oscar's Epigrams: Some Excerpts from Yesterday's Evidence"-in order to illustrate the "strange attitude adopted by this 'lover of the beautiful," " the Evening News's reporting foregrounds Wilde's words as the source of evidence about "the strange personality." That the newspaper text conjoins Wilde's "wonderful intellectual force and flow of perfect language" with the "curious tone of his epistolary prose sonnets" and "the bizarre nature of his chance acquaintances" in order to report his "performance" as a witness reveals the constellation of meanings from which Wilde's "extraordinary character" emerges. Yet, since Wilde's replies to Carson also called into question the very logic of interpretation upon which such characterological claims were predicated, the representations of his cross-examination once again inscribe Wilde's texts as a primary site over which the contest of meanings takes place.

At a schematic level, Carson's cross-examination can be chronologically divided into two parts: the first occupied the terrain of Wilde's writing and the second his life/style. While this division unfolded temporally in the courtroom, however, its mediated appearance in the press established a logic of insinuation in which the sexual presumptions attributed 
[Vol. 5: 1

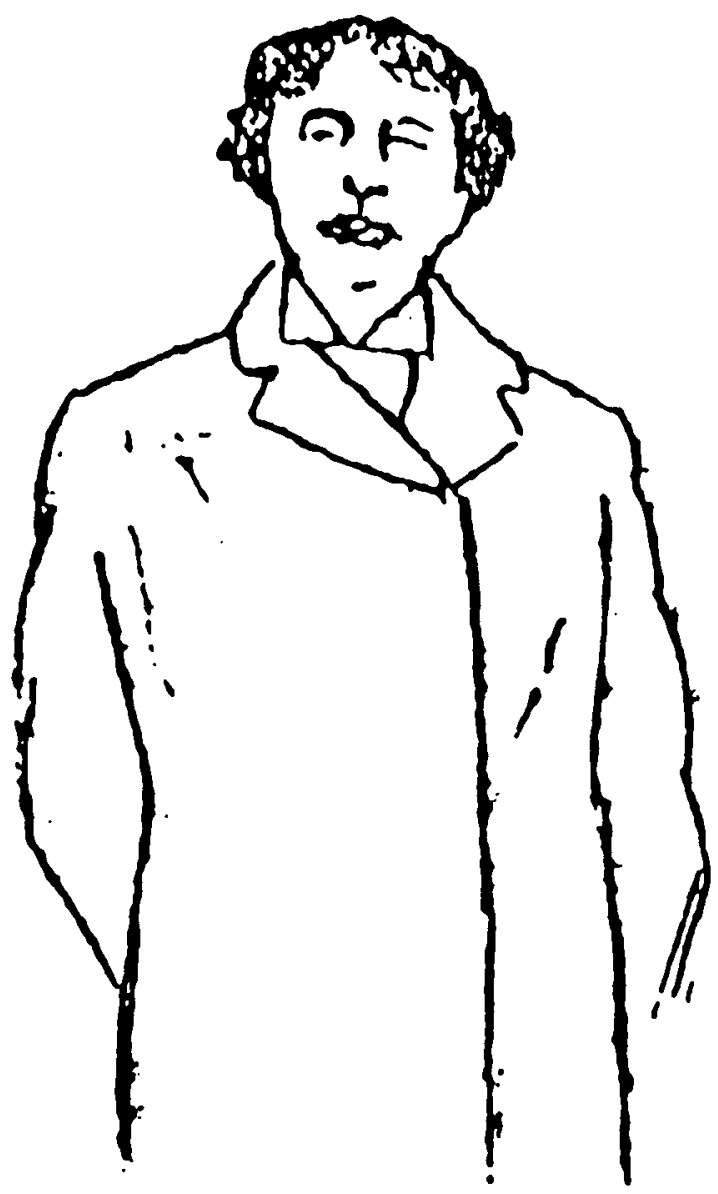

he. Orcar Titru.

Figure 8. The Evening News, 4 April 1895.

to Wilde's writings during the earlier part of the questioning were reiterated in the second part (conveniently occurring almost entirely on the second day of testimony) as evidence of the sexual quality of his relationships with several younger, working-class men. To this end, Carson began his inquiry by addressing what he perceived as the sexual implications of a series of "literary" works: Alfred Douglas's poems "Praise of Shame" and "Two Loves," a short story by John Francis Bloxham in The Chameleon called "The Priest and the Acolyte," Wilde's "Phrases and Philosophies for the Use of the Young" (appearing in the same issue of The Chameleon), The Picture of Dorian Gray, Huysmans's $A$ rebours, as well as several letters from Wilde to Alfred Douglas. In each case Carson sought to introduce to the court a text whose "meaning" he asserted was "improper," "immoral," "blasphemous," or "unnatural" 
and then to deduce from these "meanings" a moral equivalence between the writing and Wilde-even when he was not the text's author. While the pattern of questioning is quite similar for all the texts named, with Carson asking Wilde if a "certain" interpretation could not be drawn from the work in question and Wilde replying that such interpretations were predicated on a naive reading process, the interrogation concerning The Picture of Dorian Gray surpassed all others in developing this strategic exchange. Here the activities and attitudes ascribed to Wilde's characters become the pretext for direct imputations made about Wilde's own "character." Since the Daily Telegraph (4 April) provides one of the most detailed versions of this metonymic slide, it is worth considering its somewhat lengthy account here.

This is your introduction to "Dorian Gray": "There is no such thing as a moral or immoral book; books are well written or badly written." That expresses your view? - My view on art, yes.

Then a well written book putting forth certain views might be a good book? -No work of art ever puts forth views of any kind. Views belong to people who are not artists.

Is "Dorian Gray" open to certain interpretations? -Only to brutes and illiterates. The views of the Philistine on art are incalculably stupid.

The majority of people would come within your definition of Philistine and illiterates? - I have found wonderful exceptions.

Do you think the majority of people live up to the pose you are giving us? - I am afraid they are not cultivated enough.

Not cultivated enough to draw the distinction you have done between a good book and a bad book? - Certainly not. It has nothing to do with art at all.

You don't prevent the ordinary individual from buying your books? -I have never discouraged it. (laughter)

Mr. Carson then read a passage describing the introduction of the artist to Dorian Gray and asked: Do you consider the feeling there described as a proper or improper feeling?

Witness: I think it is the most perfect description possible of what an artist would feel on meeting a beautiful personality that he felt in some way or other was necessary to his art and his life.

You think that is a moral kind of feeling for one man to have toward another? -I say it is the feeling of an artist toward a beautiful personality.

You have never known the feelings you describe there? -No. I have never allowed any personality to dominate my art.

Although the accounts appearing in other papers differ substantially at 
times from this one, ${ }^{22}$ the movement from text to (authorial) context remains constant in each. As the Telegraph represents it, the crossexamination seems to juxtapose Carson's assertions about Dorian Gray's "(im)morality" to Wilde's claims that the power of art obviates such monologic "views." Yet, since Carson seems to have quickly subsumed the question of morality under that of public opinion, Wilde's "aesthetic" replies situate him in opposition to "the ordinary person" so that he seems to constitute himself as "extraordinary." In the courtroom where the audience was to a large extent comprised of highly educated legal officials, such an implication might have been received with relatively little disapprobation, if not actual approval, as the reported laughter seems to suggest. But as soon as the remark was reiterated in the daily press where the readership was necessarily constituted by-and was perhaps even definitive of - the "ordinary reader," Wilde's remarks could be seen as corroborating the defense suggestions made against him (see the Evening News's use of "ordinary"/"extraordinary" above). By foregrounding the issue of Wilde's "character," then, this questioning privileges the interpretation of Wilde through his texts, so that there is little rocm for distinguishing between them. The newspaper report makes this association between writer and writing even more explicit when it omits the passages from The Picture of Dorian Gray read aloud in the trial, so that instead of appearing to refer to the characters in his novel, the references to "the artist" seem to evoke Wilde himself. Hence, Wilde's statement concerning "what an artist would feel on meeting a beautiful personality" can appear quite logically to signify his own relation to Lord Alfred Douglas, thereby undermining his assertion that he had "never allowed any personality to dominate [his] art."

This effective equation between Wilde's aesthetic and sexual ideologies appears even more unequivocally in the more "dramatic" press accounts of the "literary" testimony that appeared in the Echo, the Star, and the Morning Leader. For these highly condensed, overly and overtly narrated versions do not hesitate to emphasize the (sexual) implications that the testimony itself usually leaves unspoken, even when such emphasis leads to blatant misreporting.

As to your works, you pose as not being concerned about morality

22. For example, in the version that appeared in the Evening Standard, the exchange about what "kind" of book The Picture of Dorian Gray was appeared as follows:

Then a well written book putting forward certain views might be a good book? - No work of art ever puts forward views. Views belong to people who are not artists.

A - novel might be a good book? -I don't know what you mean by a - novel.

Then I will suggest "Dorian Grey" [sic] as open to the interpretation of being a - novel?

- That could only be to brutes and illiterates.

An illiterate reading "Dorian Grey" might consider it such a novel? - The views of illiterates on art are unaccountable. I am concerned only with my view of art. I can't care twopence what other people think of it. 
or immorality. The aim is to try to make the thing have some quality of beauty or of emotion? -I really [sic] think anything I write is true. (laughter) With regard to the story of "Dorian Gray," he said additions were made to it when published in volume form, and one in particular, in consequence of its being pointed out to the witness that the sin of Dorian Gray might be misconstrued. . . .

Mr. Carson-In your introduction to "Dorian Gray" you say, "There is no such thing as moral or immoral literature; a book is either good or bad"? - Yes.

A novel suggesting a serious offense might be a good book according to you? -I don't know what you mean by such a book.

I suggest "Dorian Gray." - There are things that cannot be appreciated by brutes and the illiterate.

Mr. Carson read further passages from the novel, and the witness in every case repudiated the insinuation that felonious conduct was necessarily suggested. (Echo, 3 April)

Presently the cross-examination got into deeper and deeper waters still, and Oscar was found saying, "I don't believe that any book or work of art ever produces any effect on conduct at all"-and was forthwith launched upon a long discussion of the art and morals question with Mr. Carson. He presently said that his writings must not be tested by truth in the sense of correspondence with fact. Anything was good he said, which stimulated thought. To realize oneself through pleasure was finer than to realize oneself through pain. And so forth, and

\section{DEEPER AND DEEPER STILL}

till the Irish Q. C. was left hopelessly floundering. Oscar blandly ran his fingers through his hair, and beamed on his cross-examiner, while overwhelming him with metaphysical definitions and "half truths put in an amusing and paradoxical form."

"What the sins of 'Dorian Gray' are no one knows," Mr. Wilde had written in answer to a reviewer. "People might think it meant unnatural vice?" suggested Mr. Carson. "Every man would see his own son [sic] in Dorian Gray," said Mr. Wilde. (Star, 3 April)

"What the sins of 'Dorian Gray' are no one knows," Mr. Wilde had written in answer to a reviewer. "People might think it meant unnatural vice?" suggested Mr. Carson. "Every man would see his own sin in Dorian Gray," said Mr. Wilde.

"A book which puts forward vicious views might, if you are right, be called a good book?" suggested Mr. Carson.

"No work of art ever puts forward views," Oscar sententiously replied. "Dorian Gray could only be called vicious when misinterpreted by the vulgar and the illiterate. The

\section{VIEWS OF THE PHILISTINE}

upon art are incalculable" and Oscar had "no knowledge of the ordinary individual." 
"You don't mind the ordinary individual buying your book? -I have never discouraged him.

Mr. Carson asked the prosecutor if he had ever experienced the sentiments he attributed to the painter Basil, and whether he thought them natural.

"I should think it perfectly natural," Oscar replied, "to intensely adore and love a younger man. It is an incident in the life of almost every artist."

Is it an incident in your life? Have you ever adored madly a man some 20 years younger than yourself? - No-not madly. (Morning Leader, 4 April)

In the Echo's account, Wilde's testimony is first misquoted ("really" is substituted for "rarely") so as to obscure both the force and the humor of his speech and then in a supposed paraphrase is transposed so that it appears to imply that Wilde accepted the suggestion "that the sin of Dorian Gray might be misconstrued" and altered his manuscript as a consequence (when indeed he had denied that any such motive underlay the revisions for the bound volume). Yet beyond simply misreporting "the facts," the Echo's text selectively juxtaposes apparently direct, but actually deracinated, quotations from the exchange between Wilde and Carson to its narrative conclusion that "the witness in every case repudiated the insinuation that felonious conduct was necessarily suggested," and thereby paraleptically affirms this "necessity" in the person of Wilde himself. The Star's version similarly misreports Wilde's testimony (tellingly substituting the word "son" for "sin" in the sentence "Every man would see his own son in Dorian Gray") and uses paraphrase to privilege the "immoral" interpretation of Wilde's text. Here however, the narrative interventions overshadow the effects of these (mis)reporting techniques: the emphatic repetition (in bold-faced, capital letters) of the phrase "deeper and deeper... still"-which suggests both getting closer and closer to the "truth" of the matter and getting more and more enmired in the morass of iniquity where the upright Carson "hopelessly flounder[s]"-is juxtaposed to the description of Wilde's physical and verbal presence. Hence, Wilde is represented as sharing his character's trajectory through the Victorian underworld, which "people might think ... meant unnatural vice." The Morning Leader, in turn, first singles out Wilde's manner for explicit disapprobation ("Oscar sententiously replied") which it then compounds by conspicuously reiterating Wilde's apparent claims to self-distinction: "Oscar had 'no knowledge of the ordinary individual." " "Oscar" thus comes to signify an "extraordinary individual" who believes that "it is perfectly natural to intensely adore and love a younger man." While perhaps in many ways this statement approaches the philosophy that Wilde asserted in his life, it is certainly not the one he enunciated in the courtroom; however, the Morning 
Leader abjures the actual testimony given so that it can move from the imputation made against Wilde's novel to the imputation made against Wilde himself ("Have you ever adored madly a man 20 years younger than yourself? -No-not madly."). That all three newspaper texts portray Wilde through Carson's reading of The Picture of Dorian Gray illustrates how the journalistic representations of the legal proceedings conjoin "the sexual" and "the textual" and underscores the way that Wilde's "character" served to mediate between them.

Since this representational conjunction effectively introduced the accounts of the ensuing cross-examination-which proceeded to question the (sexual) implications of Wilde's relationships with the men named in the plea of justification-it established an interpretive frame for how these relations between men could/should be read. Conveniently, the transition between the literary and life/style portions of the testimony occurred during Carson's interrogation about the "prose sonnet" from Wilde to Alfred Douglas where the shift to interpreting Wilde's behavior as a signifier of his "character" appeared to derive logically from the interpretation of his text. As Carson moved from the close scrutiny of the letter's rhetoric to the issue of the blackmail itself, he carefully imbricated his interpretation of the text's "meanings" with a salacious description of the milieu in which it had monetary value. Accordingly, he shifted the focus of his inquiry from the implications of Wilde's writing to the implications of Wilde's relationships. As the descriptions of these interactions were then subjected to the same hermeneutic process that had been established for the textual interpretations that preceded them, they came to define the basis for an indictment both of Wilde's prose and of his "pose." To a large extent, then, Carson's questions to Wilde were not intended to elicit the explicitly sexual aspects of his interactions with the various men named in the plea. Instead, they sought to reiterate the parallel between the textual and the sexual by foregrounding precisely those aspects of Wilde's life that seemed to corroborate the "immorality" of his texts.

The press reports of these aspects that emerged from the libel proceedings articulated them as elements in a story whose narrative development was predicated on establishing the kind of person that Wilde was. ${ }^{23}$ As the defense undertook to incriminate Wilde's behavior in his relationships with several younger, (usually unemployed) working-class men, it did not overtly charge him with sexual transgressions but instead intimated that his "friendships" with them could not be "proper" because they were marked by gross disparities in class, age, position, and social and educational background.

23. In my Talk on the Wilde Side, 173-209, where I address the reporting of Wilde's prosecutions for committing "acts of gross indecency with another male person," the process by which Wilde's acts became the signifiers of a certain kind of sexual actor is considered at length. 
There was the fact that in not one of these cases were the parties upon an equality with Wilde in any way. They were not educated parties such as he would naturally associate with and they were not his equal in years, and there was a curious similarity between the ages of each of them. ... They were out of employment, and of their antecedents Wilde professed to know nothing. All of them were from 18 to 20 years of age, or thereabouts, and in the manner of their introduction to Wilde and his subsequent treatment of them all were in the same category, leading to the same conclusion that there was something unnatural and what might not ordinarily be expected in the relations between them. (Evening Standard, 4 April)

The defense statement makes the implications of Carson's questioning explicit: Wilde had transgressed those boundaries of difference (class, age, education, etc.) that delimited the realm of "natural association" for the Victorian middle class and hence his relationships could "logically" be perceived to signify "something unnatural," or at least "what might not ordinarily be expected." These signifiers of difference(s) then were reiterated as Wilde was asked to describe the rooms in which he met with the younger men, the restaurants in which they ate, the gifts that passed between them, all in order to underscore the implication that these relationships could not have taken place within the sphere of "normal" behavior. Although it appears that Carson did ultimately ask Wilde in most cases whether or not he had engaged in what the papers concur in referring to as "improprieties" with the men in question, his intention was not to prove that Wilde had committed any specific acts (since Wilde would hardly have admitted this in any case) but instead to suggest that the very fact of these relationships was improper. Thus, in glossing this testimony, the Evening News described it atmospherically by alluding to the milieu that Carson evoked rather than any sexual behavior per se:

[T] he Old Bailey recoiled with loathing from the long ordeal of terrible suggestion that occupied the whole of yesterday when the cross-examination left the literary plane and penetrated the dim-lit, perfumed rooms where the poet of the beautiful joined with valets and grooms in the bond of silver cigarette cases. (5 April)

Here the personified court becomes a metonym for the larger public whose values it (supposedly) enforces and hence serves to emphasize the public horror provoked by the "ordeal of terrible suggestion." However, when the content of this ordeal is actually specified, it seems to consist entirely in the "bond" between "the poet of the beautiful" and "valets and grooms." By denoting these (sexual) actors solely by their occupations-and implicitly by their class and social status-the Evening News underscores the suggestion that no matter what might actually have or have not happened between them, the very conjunction of these men from different social positions itself constituted an "unnatural" relation. 
It is this interaction across what were (ideologically) defined as "natural" differences, then, that constituted the basis for the press reporting on Carson's indictment of Wilde's actions.

In the opening statement for the defense that followed the conclusion of the cross-examination, Carson carefully laid out the grounds on which he deemed the Marquis of Queensberry justified in claiming that the text "For Oscar Wilde, Posing as a somdomite" was both true and for the public benefit. Detailing the terrain that he had staked out in his crossexamination, Carson summarized the "literary portion" of the case and then explicitly connected it to the imputations made against Wilde's friendships with the younger men by claiming that Wilde's (sexual?) influence on Alfred Douglas-the very influence that Queensberry's card was allegedly attempting to disrupt-could be read in the text of Douglas's poems. As the Evening Standard provides a version substantially identical to those appearing elsewhere, it can serve as a model for the journalistic representation of Carson's tactic:

The poem was written by Lord Alfred Douglas and was seen by Mr. Wilde before its publication. Was it not a terrible thing that a young man on the threshold of life, who had been for several years dominated by Oscar Wilde, and who had been "loved and adored" by Oscar Wilde as his letters proved, should thus show the tendency of his mind upon this frightful subject?

That Douglas's poem (presumably "Two Loves") becomes a site for interpreting the effects of Wilde's "domination"-which the rhetorically deft narrator syntagmatically links to his "love" and "adoration"-illustrates the extent to which Wilde's "character" is continually articulated not as merely an embodied sexual proclivity but as a "tendency of mind." This mental inclination serves to identify Wilde both as one who has a "frightful" habit of thought (or at least subject matter) and who inscribes this habit in his words and deeds. Thus, two sentences later the Standard will paraphrase Carson's discourse on The Picture of Dorian Gray by parenthetically noting: "The learned Counsel read a long extract from 'Dorian Gray' with a view of maintaining that his contention was, as to the tendency of the book, right." It is this "tendency" then that the court affirmed when on Sir Edward Clarke's withdrawal of Wilde's prosecution, it found that the Marquis of Queensberry was justified in his statement about Wilde's "pose."

Since my intention here is not to analyze the legal proceedings themselves but rather the effects of their public mediations in the press, I will not address the complex legal issues raised by the abrupt termination of Wilde's prosecution (which occurred at this point in Carson's opening for the defense). Instead, I will conclude by considering two editorials that appeared on Saturday 6 April 1895, the day after the conclusion of Wilde v. Queensberry and the day of Wilde's indictment for committing 
"acts of gross indecency with another male person." The first of these pronouncements appeared on the front page of the Westminster Gazette under the headline "ART" and contained the following assessment of the case:

Every reader of our columns, as he passed his eye over the reports of WILDE'S apology for his life and work at the Old Bailey must surely have realized, with accumulating significance at every line, the terrible risks involved in certain artistic and literary phases of the day. Art we are told has nothing to do with morality. But even if this doctrine were true, it has long ago been perverted, under the treatment of the decadents, into a positive preference on the part of "Art" for the immoral, the morbid, and the maniacal. It is on this narrower issue that the proceedings of the last few days have thrown so lurid and convincing a light. We have no desire to revive here the memory of any of the degraded literature which it was $\mathrm{Mr}$. CARSON'S painful duty to exhibit in its true tendency at the Old Bailey. . . . No man-and still more, no community-has ever succeeded in setting "Art" and thought in a vacuum and, hermetically sealing it off from emotion and conduct. The theory that you may think anything without being immoral is followed in due course, if it is not even preceded, by the theory that you may do what you think. Then at length comes the discovery that the whole thing rests on a base of rottenness and corruption. There is nothing new in this; it has been seen over and over in the history of the world, and the end is always the same. It has not gone far in England, for the Philistine element is strong to check the excesses of the artistic temperament. But it has gone far enough, and the crushing exposure which has come in this case will, we hope, give pause to some who have followed, either in sheer thoughtlessness or in the perverted notion that they have a mission to emancipate "Art" from the discipline of civilized mankind.

Here the Westminster Gazette offers its commentary as a form of moral didacticism which it then juxtaposes to the "immoral" claims proffered in "Wilde's apology for his life and work." As such its concluding query ("[W]ho can doubt that the public attention called to the present case will have a most salutary effect, in many different directions, upon those who are hovering in a state of moral obfuscation caused by the decadent theory of 'Art for Immorality's sake'?") underscores the role that the press coverage had in (re)producing the "proper" public meanings that could be culled from the proceedings. Yet what precisely were those meanings that the Westminster Gazette's editorial sought to privilege? The paper first attempts to foreground the "naturalness" of the case's "significance" by asserting that its readers "must surely have realized ... the terrible risks involved in certain artistic and literary phases of the day" - even while the necessity for an extended analysis would appear to 
belie the very obviousness of these meanings. Articulating the "true tendency" that Carson was able to discern in Wilde's texts as its "natural" meaning, this interpretation marks out the aesthetic as a realm of social instability. Estranged by the "decadents" from the healthy influences of "morality," "Art" becomes simply a catalogue of degenerative pathology: it is "perverted," "immoral," "morbid," "maniacal," and "degraded." Yet, as this list of adjectives suggests, the art works that are illuminated in the "lurid light" cast by the trial are not themselves at issue; rather, they are significant only in so far as they represent the negation/antithesis of normative social standards (i.e., the "normal," "moral," "healthy," "sane," and "perfect"). In this (con)text, "Art" functions as a metonym for the proliferation of "painful" counterhegemonic meanings and practices that Wilde's voice (here equated with his "decadent" writings) introduced during the trial. For clearly, even in choosing "ART" as its title, the text signals its attempt to displace the revelations about Wilde's transgressive-or perhaps subversive-sexual and artistic practice onto the desexualized abstraction of aesthetic production. Thus, "Art for Immorality's sake" becomes a metaphor that knowingly alludes to the sexual implications made against Wilde while simultaneously suppressing the direct expression of this knowledge.

In enunciating its own counteraesthetic, then, the Westminster Gazette is not just propounding a theory of artistic production, or even simply trying to situate this production within a social context; rather, it is defining the position of hegemonic (re)production and reinscribing Wilde within it. Through the strategic use of negation, the text rhetorically invokes its authority to speak with the voice of universal truth ("no man," "no community," "nothing new") so that it implies the timelessness of its utterance. Since from this transcendent vantage point, "Art" and "thought" stand in an inextricable relation to "emotion and conduct," intellectual transgressions such as Wilde's must necessarily, or at least by way of a broken syllogism, provoke social anarchy and lead to cultural degeneration. Asserting that this regressive sequence reiterates a pattern that "has been seen over and over in the history of the world, and the end is always the same," the passage links Wilde's artistic and sexual practices to the fall of empires, even as it disdains to mention these practices explicitly. Thus, as the (pseudo)logical movement of this passage reveals, what is ultimately at stake in this moral evaluation of "Art" is the future of-in the author's unconsciously imperialist terminology"the discipline of civilized mankind." Simultaneously evoking both a belief in the "natural" superiority of the British empire (over and against the "uncivilized" both at home and abroad) and a sense of the precariousness of this national and global ascendency (dependent as it was on a strict adherence to discipline), this last phrase must have conveyed to its 
presumably middle-class audience the importance of affirming their own moral and cultural rectitude. That Wilde's case should become the impetus for such a radical reassertion of "civilization's" moral ground suggests that the unarticulated assumptions that underlay the newspaper coverage of the trial negatively infused into the figure of Wilde those presumptions that define the "British" masculine norm.

The Daily Telegraph's assessment of the verdict against Wilde made this connection even more explicit. Beginning with a brief summary of the trial's denouement, the Telegraph foregrounds Wilde's exemplary role both in the proceedings and in the nation.

As for the prosecutor, whose notoriety has now become infamy, he made no appearance yesterday upon the scene, and he has since been arrested at the insistence of the Treasury on a charge of a very grave character. This being so, as regards any further influence which he can exercise upon social, literary, or artistic matters, and the contempt and disgust felt for such a character being fully met by the hideous downfall of the man and of his theories, we may dismiss the prisoner without further remark. We have had more than enough, of MR. OSCAR WILDE, who has been the means of inflicting upon public patience during this recent episode as much moral damage of the most offensive and repulsive kind as any single individual could well cause. If the general concern were only with the man himself-his spurious brilliancy, inflated egotism, diseased vanity, cultivated affectation, and shameless disavowal of morality-the best thing would be to dismiss him and his deeds without another word to the penalty of universal condemnation. But there is more than the individual himself to be considered in the matter. The just verdict of yesterday must be held to include with him the tendency of his peculiar career, the meaning and influence of his teaching, and all those shallow and specious arts by which he and his like have attempted to establish a cult in our midst, and even to set up new schools in literature, the drama, and social thought.

The "very grave character" of the charge on which Wilde was arrested serves to define Wilde as "such a character" as embodies the "social, literary, or artistic"-not to mention sexual-implications of the unnamed offense. By rendering Wilde's name in small caps, the text constructs him as the point of origin of the "moral damage of the most offensive and repulsive kind," thereby obscuring the fact that it was not Wilde but the newspapers themselves that "inflicted" these indignities upon the "public patience." Yet the editorial does not attempt to confine the "immoral" meanings that "Wilde" generates to "the man himself," even though it takes pains to articulate them very specifically, but instead seeks to transform his "character" into an example of "the tendency of his particular career." This movement from "character" to "tendency" then constructs "Wilde" as an "immoral character" who comes to sig- 
nify the unnamed "charge of a very grave character" in order to warn the public against the dangers of " $\mathrm{h}[\mathrm{im}]$ and his like."

But what are these dangers that the Telegraph so emphatically seeks to warn its readers of? In elucidating the implications of Wilde's transgressions, the paper leaves no doubt as to what it believes to be at stake.

It will be a public benefit, compensating for a great deal that has been painful in the reports of this trial, if the exposure of a chief representative of the immoral school leads to a clearer perception of its tendency and a heartier contempt for its methods. There is nothing difficult to understand in the principles of such people or in the results to which they lead. The aestheticism which worships a green carnation or a perfume has lost so much the sense of what is precious in parental and filial relations that we saw in this case a son addressing his father in terms which in ancient days would have involved his death. The superfine "Art" which admits no moral duty and laughs at the established phrases of right and wrong is the visible enemy of those ties and bonds of society-the natural affections, the domestic joys, the sanctity and sweetness of the home. We may judge this curse of an outrageous cult best when we find it the sworn and desperate opposite of the sacred verse which runs, "Whateverso things are true, whateverso things are honest, whateverso things are just, whateverso things are pure, whateverso things are lovely, whateverso things are of good report, if there be any virtue, and if there be any praise, think on these things." A nation prospers and profits precisely by those national qualities which these innovators deride and abjure. It goes swiftly to wreck and decay by precisely that brilliant corruption of which we have just had the exposure and the demonstration.

Characterizing the "tendency" of which Wilde is "a chief representative" as antithetical first to the authority of father over son and then by extension to the larger social organization articulated as the "nation," this quotation identifies the social order with the "natural affections" embodied within Victorian domesticity and simultaneously inscribes Wilde as their "visible enemy." In other words, it foregrounds the "sacredness" of the bourgeois home as the condition of "national prosperity" by representing "Oscar Wilde" as the "sworn and desperate opposite" of all that seems to guard against "wreck and decay." Here the "immorality" of Wilde's aesthetic ideology serves as an index for his transgressions, which, by moving across those boundaries that seem to guarantee national security, place him outside the world symbolized by the "sanctity and sweetness of the home." This positioning then serves to construct Wilde as the embodiment of a threatening "difference" so that he becomes the figure for a counternormative masculinity that both violates and transforms Victorian opposition between domestic and public spheres. 
It was this threat that the Crown's prosecution of Wilde was intended to contain.

\section{EPILOGUE}

The withdrawal of Wilde's prosecution and the determination that the Marquis of Queensberry was "justified" in his claim that Wilde had "posed as a sodomite" terminated the libel proceedings in Wilde $v$. Queensberry. Yet this was far from the conclusion of Wilde's legal ordeal.

Schematically, the sequence of legal events that concluded on 25 May 1895 with Wilde's sentencing to two years' imprisonment with hard labor can be chronicled as follows: After his initial arrest (5 April) and subsequent formal indictment (25 April) for committing acts of gross indecency and conspiring to commit such acts along with Alfred Taylor-an unemployed gentleman of Wilde's acquaintance who had recently run through a small inheritance, arrested on 6 April, and additionally charged with procuring young men for Wilde-the two defendants were remanded to police custody without bail until the indecisive conclusion of the first prosecution on 1 May. During the four days of testimony given in Regina v. Wilde and Taylor, Wilde once again assumed the witness stand, this time followed by his codefendant, and their appearances-especially Wilde's eloquent defense of "The love that dares not speak its name"-seem to have been instrumental in causing the jury to disagree as to their guilt or innocence on the charges. The Crown then arranged to retry the case at the next session of the Old Bailey, at which time the prosecution was assumed by the solicitor general, Sir Frank Lockwood, a move that both signaled the political/symbolic importance of the prosecution and shifted the weight of presumption against the defendants. (Under British legal practice the solicitor general, unlike any other prosecuting barrister, always has the right to speak last before the jury.) Since the conspiracy charges were determined to be unfounded during the course of the first trial, the second prosecution separated Wilde and Taylor's adjudications so that Taylor was brought up again on 21 May and found guilty on 22 May, whereupon the prosecution against Wilde recommenced and he was found guilty on 25 May of seven counts under section 11 of the Criminal Law Amendment Act. Both men were then sentenced together to two years' imprisonment with hard labor, the maximum penalty allowed by law.

On 25 May 1895, Wilde's imprisonment began and the newspaper stories about him-like his body itself-largely disappeared from public view. With the exception of a brief set of court appearances during his adjudication for bankruptcy later the same year, when crowds gathered near the court buildings in the hope of catching a glimpse of the infa- 
mous prisoner and the newspapers briefly noted this renewed interest, Wilde's moment as the focus of public attention had passed. After his emergence from prison on 19 May 1897, Wilde was never able to resume his earlier writing career, publishing only "The Ballad of Reading Gaol" before his death on 30 November 1900 . In the years between his release from prison and his untimely demise, he lived primarily in France, sometimes under a pseudonym, Sebastian Melmouth-so overdetermined had his own name become that it was difficult even for its bearer to acknowledge in the land of his exile. 
